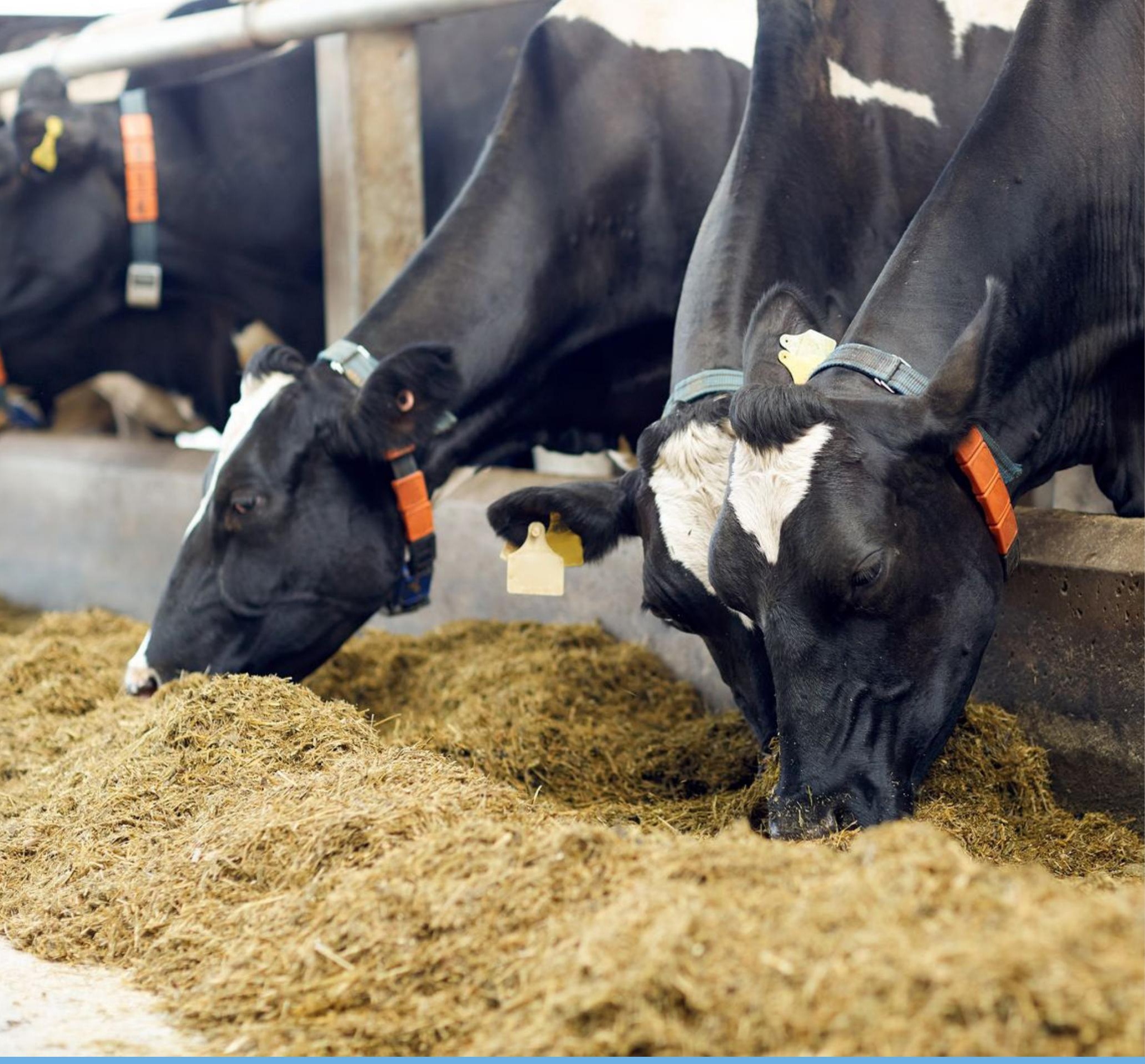

Relaties tussen acidose in de pens, in de darm en in het metabolisme van melkvee tijdens de vroege lactatie 



\section{Relaties tussen acidose in de pens, in de darm en in het metabolisme van melkvee tijdens de vroege lactatie}

Deskstudie

A. Bannink, J. Dijkstra, S.J. Koopmans
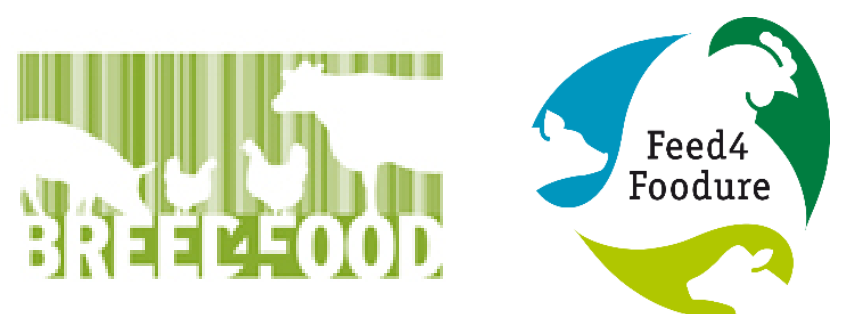

Dit onderzoek is uitgevoerd door Wageningen Livestock Research, in het kader van de Publiek Private Samenwerking "BreedFeed4Food" (AF-14215), medegefinancierd door het Ministerie van LNV (BO-47-001-008) en door de Vereniging Diervoederonderzoek Nederland (VDN).

Wageningen Livestock Research

Wageningen, december 2018 

Bannink, A., J. Dijkstra, S.J. Koopmans, 2018. Relaties tussen acidose in de pens, in de darm en in het metabolisme van melkvee tijdens de vroege lactatie; Deskstudie. Wageningen Livestock Research, Rapport 1139.

\section{Samenvatting}

Uit deze deskstudie blijkt dat de energetische kosten die gemoeid zijn met het reguleren van het zuurbase evenwicht in de melkkoe en het corrigeren van een verzuring (acidose) naar verwachting een aanzienlijk deel uitmaken van de energetische onderhoudsbehoefte van vitale organen en de gehele koe. Dit betekent dat acidose op pensniveau, dikke darmniveau of op het niveau van het metabolisme van de koe een belangrijke invloed kan hebben op het functioneren van de melkkoe. Er is nauwelijks experimenteel onderzoek beschikbaar rondom de mogelijk negatieve invloed van acidose (met name in de dikke darm en metabool) op het functioneren van de melkkoe tijdens de vroege lactatie. Er zijn aanwijzingen voor een dergelijke negatieve uitwerking en voor de interactie tussen het optreden van acidose, de metabole status van de melkkoe en de gezondheidsproblemen die dikwijls in deze periode optreden. Mogelijke interacties tussen acidose op het niveau van de pens, de dikke darm en het metabolisme worden bediscussieerd. Invloedfactoren bij een pensacidose, een dikke darmacidose en een metabole acidose worden opgesomd. Een overzicht wordt gegeven van de kenmerken van de fysiologische status van een melkkoe tijdens de vroege lactatie, van de metabole fenomenen die samengaan met het optreden van een acidose op een van de drie niveaus, en van de directe oorzakelijke factoren en processen die betrokken zijn bij het ontstaan van een acidose.

\section{Summary}

This review indicates that the energetic costs associated with the regulation of acid-base equilibrium in the dairy cow and the required adjustments with acidification (acidosis) are expected to be a considerable portion of the energy requirement of vital organs and the whole cow. This implies that acidosis at the rumen level, at the large intestinal level or at the metabolic level may have a significant impact on cow performance. Experimental research around the potentially negative effects of acidosis (particularly in the large intestine and metabolically) on cow functioning during early lactation is lacking however. There are indications for such negative effects and for the interaction between the occurrence of acidosis, the metabolic state of the dairy cow and impaired health which often occurs during this stage of lactation. Possible interactions between acidosis at the rumen, the large intestinal and the metabolic level are discussed. Influencing factors for acidosis in the rumen, the large intestine and metabolically are listed. An overview is given of features of the physiological state of a lactating cow during early lactation, of the metabolic phenomena that go together with the occurrence of acidosis at one of the three levels, and of the direct causal factors and processes involved with the development of such acidosis.

Dit rapport is gratis te downloaden op https://doi.org/10.18174/465646 of op www.wur.nl/livestock-research (onder Wageningen Livestock Research publicaties).

(C) 2018 Wageningen Livestock Research

Postbus 338, 6700 AH Wageningen, T 03174839 53, E info.livestockresearch@wur.nl, www.wur.nl/livestock-research. Wageningen Livestock Research is onderdeel van Wageningen University \& Research.

Wageningen Livestock Research aanvaardt geen aansprakelijkheid voor eventuele schade voortvloeiend uit het gebruik van de resultaten van dit onderzoek of de toepassing van de adviezen.

Alle rechten voorbehouden. Niets uit deze uitgave mag worden vermenigvuldigd en/of openbaar gemaakt worden door middel van druk, fotokopie, microfilm of op welke wijze dan ook zonder voorafgaande toestemming van de uitgever of auteur.

Wageningen Livestock Research is NEN-EN-ISO 9001:2015 gecertificeerd. Op al onze onderzoeksopdrachten zijn de Algemene Voorwaarden van de Animal Sciences Group van toepassing. Deze zijn gedeponeerd bij de Arrondissementsrechtbank Zwolle. 



\section{Inhoud}

$\begin{array}{ll}\text { Woord vooraf } & 7\end{array}$

$\begin{array}{ll}\text { Samenvatting } & 9\end{array}$

$1 \quad$ Inleiding

11

2 Achtergronden verzuring, zuurgraad regulatiemechanismen en hun aandeel in $\begin{array}{ll}\text { de energiehuishouding } & 12\end{array}$

12

2.1 Compartimentering 13

2.2 Kosten in stand houden homeostase (zuur-base evenwicht) 13

3.1 Productie en verdwijning van vluchtige vetzuren $\quad 16$

3.2 Productie en verdwijning van melkzuur 16

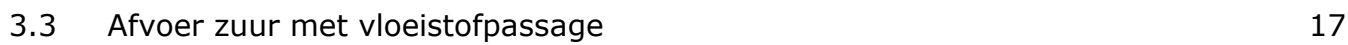

$\begin{array}{lll}3.4 & \text { Bufferen via het rantsoen } & 18\end{array}$

$\begin{array}{lll}3.5 & \text { De gevolgen van pensverzuring } & 18\end{array}$

3.6 Opsomming interessante, te onderzoeken factoren $\quad 22$

$4 \quad$ Acidose in de dikke darm $\quad 23$

4.1 Water- en elektrolytenbalans 24

4.2 De $\mathrm{pH}$ van digesta in de dikke darm, lipopolysacchariden en dikke darmepitheel 25

$\begin{array}{lll}4.3 & \text { Opsomming interessante, te onderzoeken factoren } & 25\end{array}$

$\begin{array}{llr}5 & \text { Metabole acidose } & \mathbf{2 7}\end{array}$

$5.1 \quad$ Ketose (tijdens de negatieve energiebalans na afkalven) 28

5.2 De rol van insuline en insulineresistentie bij melkvee 30

$\begin{array}{lll}5.3 & \text { Overige oorzaken metabole acidose } & 31\end{array}$

5.4 Relatie metabole acidose en pens/dikke darm acidose $\quad 32$

$\begin{array}{lll}5.5 & \text { Conclusies \& onderzoekfactoren } & 35\end{array}$

6 Interacties tussen de gevolgen van pens-acidose, darm-acidose en metabole $\begin{array}{ll}\text { acidose } & 36\end{array}$ 



\section{Woord vooraf}

Deze studie maakt onderdeel uit van de publiek private samenwerking Breed\&Feed4Food. Dit programma is een uniek samenwerkingsverband tussen diervoederbedrijfsleven, fokkerijorganisaties en enkele andere stakeholders in de dierlijke productieketen. Het programma heeft de ambitie om duurzame en gezonde veehouderij in Nederland verder te ontwikkelen. Daarbij zijn doorbraken noodzakelijk om de invloed van verschillende factoren op de dierlijke productie beter op elkaar af te stemmen. Er zijn aanwijzingen dat dierkenmerken, diervoeding, de microbiota in het maagdarmkanaal en fysiologische processen in het metabolisme van het dier nauw met elkaar samenhangen, en invloed uitoefenen op zowel productie als gezondheid. Desalniettemin worden hun effecten nog nauwelijks in samenhang met elkaar bestudeerd.

De studie richt zich op de achtergronden en gevolgen van acidose op verschillende locaties in melkvee. De studie werd uitgevoerd ter voorbereiding van experimenteel onderzoek naar de mogelijke effecten van acidose in de pens, in de darm of metabool, op het functioneren van de melkvee. 


\section{Samenvatting}

Uit deze deskstudie blijkt dat de energetische kosten die gemoeid zijn met het reguleren van het zuurbase evenwicht in de melkkoe en het corrigeren van een verzuring (acidose) naar verwachting aanzienlijk zijn. Dit betekent dat acidose op pensniveau, dikke darmniveau of op metabool niveau een belangrijke invloed kan hebben op het functioneren van de melkkoe. Er is nauwelijks experimenteel onderzoek beschikbaar rondom de mogelijk negatieve invloed van acidose (met name in de dikke darm en metabool) op het functioneren van de melkkoe tijdens de vroege lactatie. Er zijn aanwijzingen voor een dergelijke negatieve uitwerking en voor de interactie tussen het optreden van acidose, de metabole status van de melkkoe en de gezondheidsproblemen die dikwijls in deze periode optreden. Mogelijke interacties tussen deze drie typen acidose worden beschreven. Tevens wordt een opsomming gegeven van nog te onderzoeken invloedfactoren op een pensacidose, een dikke darmacidose en een metabole acidose. Een overzicht wordt gegeven van de kenmerken van de fysiologische status van een melkkoe tijdens de vroege lactatie, van de metabole fenomenen die samengaan met het optreden één van de drie typen acidose, en van de directe oorzakelijke factoren en de processen die betrokken zijn bij het ontstaan van een acidose. 


\section{$1 \quad$ Inleiding}

Verzuring (acidose) wordt dikwijls genoemd als oorzaak van tegenvallende prestaties van melkvee in met name de opstartfase na afkalven. Tijdens deze fase neemt de voeropname sterk toe, evenals het aandeel krachtvoer in het rantsoen, en lijken melkkoeien het meest gevoelig voor de negatieve uitwerking van een verzuring. Omdat er in deze periode grote veranderingen zijn in voerstrategie, voeropnameniveau en fysiologische en hormonale regulering van het metabolisme van de melkkoe, blijft het lastig om te achterhalen welke effecten nu specifiek aan het vermeende probleem van verzuring moeten worden toegekend. Discussie rondom de negatieve effecten van verzuring op de gezondheid van melkvee richten zich gericht op drie niveaus, of locaties, waar een verzuring kan optreden: in de pens en in de dikke darm (waar fermentatie en zuurvorming optreedt) en in bloed. Deze drie worden aangeduid met de term pensacidose, dikke darmacidose, en metabole acidose.

Het doel van deze deskstudie is het inzichtelijk maken 1) welke factoren een rol spelen bij het ontstaan van een verzuring, 2) hoe oorzaak en gevolg van elkaar onderscheiden kunnen worden indien het fenomeen verzuring optreedt, en 3) op welke wijze verzuring op de drie locaties in het lichaam van de melkkoe met elkaar kunnen samenhangen, of elkaar kunnen beïnvloeden. Ten slotte worden enkele aanbevelingen gedaan voor experimenteel onderzoek. 


\section{Achtergronden verzuring, zuurgraad regulatiemechanismen en hun aandeel in de energiehuishouding}

De zuurgraad in verschillende lichaamscompartimenten is sterk gereguleerd. De gastheer draagt bij aan regulering van de zuur-base condities zoals in de pens en dikke darm door al te grote schommelingen van concentratie aan zwakke zuren te voorkomen door buffering (verhoogde speeksel- of bufferproductie, hogere intreding van water) en een versnelde afvoer (verhoogde uitstroom, versnelde absorptie), of een verlaging van de productie (bijv. door verlaagde voeropname). Dit gebeurt enerzijds door te zorgen voor voldoende capaciteit voor de afvoer van deze zwakke zuren (via de absorptie door de penswand, en via vloeistofpassage) (Bannink et al., 2012; Dieho et al., 2016) en anderzijds door het aanvoeren van buffer (via de productie van speeksel, en de uitwisseling van het zuuranion met bicarbonaat bij de absorptie van vluchtige vetzuren door de penswand) (Dijkstra et al., 2012).

In essentie zijn er 5 causale factoren die de zuurgraad van de inhoud van een lichaamscompartiment bepalen (in pensvloeistof of -digesta, in dikke darm digesta of verse feces, en in bloedplasma) (Bannink \& Dijkstra, 2006):

1) de concentratie zwakke zuren (vluchtige vetzuren, melkzuur, ketonlichamen),

2) de concentratie zwakke basen (fosfaat, ammonium),

3) het concentratieverschil van sterke kationen en anionen (kalium, natrium, chloor, sulfaat; deze ionen nemen niet deel aan een zuur-base evenwichtsreactie maar zijn altijd in ion-vorm aanwezig en daarmee als sterke zuren of basen te beschouwen),

4) de partiele gasdruk van kooldioxide (mede sturend voor het evenwicht tussen de concentratie van kooldioxide, koolzuur, bicarbonaat en carbonaat)

5) aanwezige stoffen zoals eiwitten, of bestanddelen die een uitwisseling van $\mathrm{H}^{+}$of van sterke ionen teweeg brengen.

Aanvullende factoren die de zuurgraad mede kunnen bepalen (en dus een invloed hebben op het zuurbase evenwicht) zijn eiwitten en bestanddelen die een ion-uitwisselcapaciteit hebben met de vloeistof (bijv. kationen in ruwvoeders). Eiwitten hebben een sterk bufferend vermogen en spelen een grote rol bij het bufferen van de intracellulaire vloeistof in lichaamscellen.

Figuur 1. Overzicht van causale factoren voor het zuur-base evenwicht (Bannink \& Dijkstra, 2006).

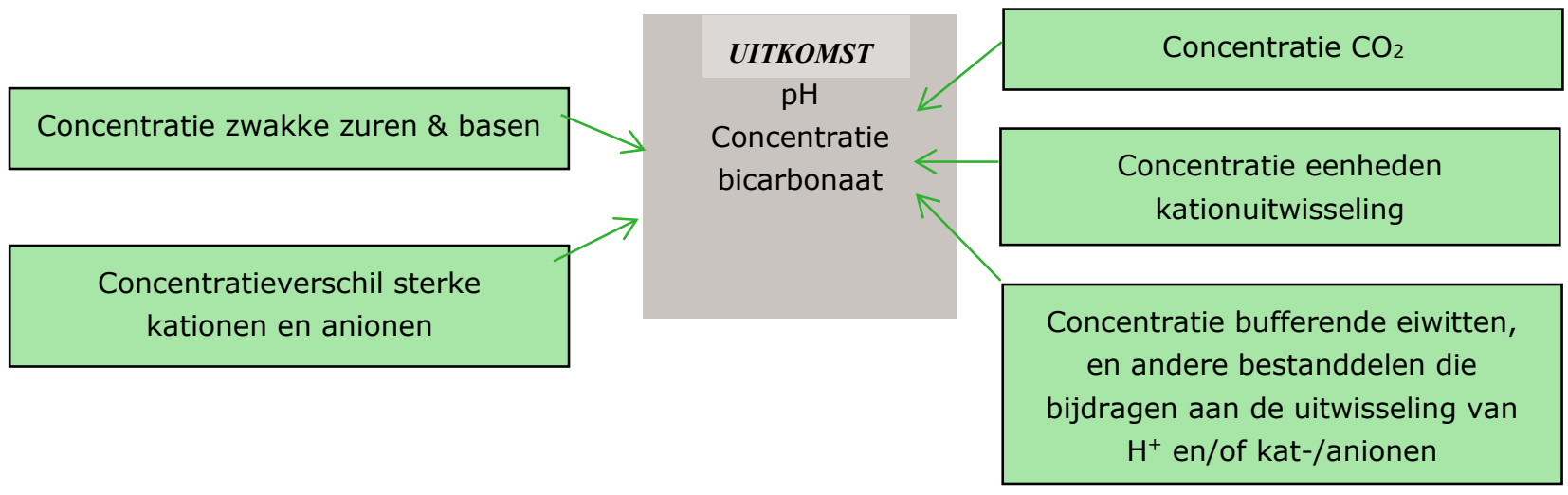




\section{$2.1 \quad$ Compartimentering}

Zowel op lokaal niveau in organen en weefsels, als op micro-niveau in de celinhoud of rondom celmembranen, is er een hoge mate van compartimentering wat ook geldt voor de zuurgraad. De zuurgraad in aaneenliggende compartimenten kan sterk verschillen. Zo kan de zuurgraad in waterfilm langs de epitheellaag in de penswand een andere waarde hebben dan de zuurgraad in de bulk aan pensvloeistof die voortdurend met de digesta gemengd wordt. De zuurgraad in de waterfilm staat direct onder invloed van ion-transport over de membraan van de epitheelcellen. Daarmee kan ook de concentratie zwakke zuren en basen in die waterfilm, en de mate waarin ze gedissocieerd zijn, verschillen van die in een monster pensvloeistof zoals dat betrokken wordt uit de pensinhoud via de pensfistel. Een apicale $\mathrm{Na}^{+/} \mathrm{H}^{+}$uitwisseling verwijdert $\mathrm{Na}^{+}$ionen uit de (unstirred) waterfilm langs het epitheel, en brengt $\mathrm{H}^{+}$ionen erin terug, wat tot een 0.3 tot 0.7 eenheden lagere $\mathrm{pH}$ in deze waterfilm kan leiden (Goff, 2018). Dit betekent dat een verzuring van de digesta in de pens niet automatisch ook dezelfde verzuring geeft in de waterfilm grenzend aan het pensepitheel, en omgekeerd. Mede dankzij de aanwezigheid van deze compartimentering is het pensepitheel als weefsel in staat het intracellulaire zuur-base evenwicht in stand te houden en kan het de zuurgraad in de directe nabijheid van het epitheel reguleren. Dezelfde principes gelden voor het zuur-base evenwicht in het epitheelweefsel van de dikke darmwand als voor die in de penswand, ook al is de aard van het epitheel (ontogenetische oorsprong), en de functionaliteit en het milieu in de dikke darm sterk verschillend. De mate van en de regulering van de zuurgraad in en rondom weefsels moet mede worden uitgelegd aan de hand van de aanwezige compartimentering.

Bij de mate van metabole verzuring ligt de situatie anders. Vanwege de bloedsomloop die doordringt tot in alle weefsels en die een directe uitwisseling kent met de vloeistof in het interstitium, en de hoge doorloopsnelheid en regulering van de samenstelling en zuurgraad van bloed, kan bloed als een enkel compartiment beschouwd worden dat in directe uitwisseling staat met alle organen. De zuurgraad van bloed wordt binnen zeer nauwe grenzen gehouden door middel van sterke regulatiemechanismen. Het redeneren over een metabole acidose richt zich dan ook volledig op de zuurgraad van bloed als directe afspiegeling daarvan. Voor de buffering van bloedplasma is naast de ion-transportmechanismen (met een belangrijke rol voor de nieren die de uitscheiding van ionen reguleert) en de verwerkingscapaciteit voor zwakke zuren en basen door de weefsels die doorbloed worden, de ademhaling een belangrijk regulatiemechanisme omdat daarmee de partiele gasdruk van kooldioxide laag gehouden wordt. Een verzurend effect van een ophoping van kooldioxide wordt tegengegaan door een toename en versnelling van de ademhaling. Ook de bufferingmechanismen van de zuurgraad van de intra- en extracellulaire en interstitiële vloeistof vindt middels deze mechanismen plaats. Bij de buffering van de intracellulaire vloeistof hebben ook intracellulaire eiwitten een belangrijke rol. Eiwitten hebben een bufferende werking en, hoewel ook in bloedplasma eiwitten voorkomen en bijdragen een het zuur-base evenwicht, lijkt deze rol veel prominenter in het intracellulaire compartiment van de cellen in weefsels. Ongeveer $60 \%$ tot $70 \%$ van de totale buffering in lichaamsvloeistoffen geschiedt intracellulair, and hierin hebben intracellulaire eiwitten het grootste aandeel met een doorsnee pKa waarde van 7.4 (https://opentextbc.ca/anatomyandphysiology/chapter/26-4-acid-base-balance). $\mathrm{Er}$ is echter een vertraging tussen een verstoring van het zuur-base evenwicht extracellulair, en de beweging van protonen en bicarbonaat door de celmembraan voor een maximale buffering door de aanwezige intracellulaire eiwitten. Daarmee zijn de eiwitten geen mechanisme die verschuivingen in het zuur-base evenwicht momentaan bufferen, maar daarentegen wel effectief voor het algehele niveau van buffering op de wat langere termijn.

\subsection{Kosten in stand houden homeostase (zuur-base evenwicht)}

De zuurgraad in lichaamsweefsels en bloed is zeer sterk gereguleerd omdat een zuurgraad die afwijkt van de streefwaarde (een nagenoeg neutrale waarde van 7.4) ernstige gevolgen heeft voor de werking en activiteit van enzymen en overige eiwitten (bijvoorbeeld van eiwitten die zorg dragen voor transport over de celmembraan). Naast een versnelde omzetting en transport van de opgenomen zwakke zuren en basen door lichaamscellen (bijv. vluchtige vetzuren, ammonium, ketonlichamen) om de intracellulaire concentratie binnen het streefgebied te houden, maken zij in hoge mate gebruik van iontransportsystemen als regulatiemechanisme. Deze ion-transportmechanismen (m.n. uitwisseling van $\mathrm{Na}^{+}$ 
en $\mathrm{K}^{+}$over de celmembraan door $\mathrm{Na} / \mathrm{K}$-ATPase, maar ook co-transport van ionen) vergen veel energie en maken een belangrijk deel uit van de energetische onderhoudsbehoefte van cellen, weefsels, organen en zelfs de gehele melkkoe (review Bannink et al., 2006). Summers et al. (1988) noemt bijvoorbeeld een gemeten bijdrage van ion-transportmechanismen aan het basale metabolisme van hepatocyten van 28 tot 55\%. Baldwin (1995) schat de bijdrage van de weefsels van de lever en het maagdarmkanaal aan de totale onderhoudsbehoefte op respectievelijk $25.6 \%$ en $8.4 \%$ voor de melkgevende koe, en op $22.5 \%$ en $7.2 \%$ voor de droogstaande koe. Dit is eenzelfde orde van grootte als het aandeel van het karkas aan de totale onderhoudsbehoefte van respectievelijk $21.9 \%$ in melkgevende koeien en $26.0 \%$ in droogstaande koeien. De bijdrage van de lever en het maagdarmkanaal aan het lichaamsgewicht is echter, respectievelijk, $5.2 \%$ en $1.8 \%$ in melkgevende koeien en $4.1 \%$ en $1.4 \%$ in droogstaande koeien, ten opzichte van een bijdrage van het karkas van respectievelijk $57.7 \%$ en $62.5 \%$. Het aandeel van iontransport aan het totale energieverbruik door weefsels van het maagdarmkanaal en de lever (gemeten als het ouabaïne-gevoelige deel van het energieverbruik) wordt geschat op, respectievelijk, 35 en $38 \%$ (Summers et al., 1988). Alleen weefsels in de nieren zijn metabool actiever en hebben een aandeel voor de bijdrage van ion-transportmechanismen aan het energieverbruik van $70 \%$. Voor lammeren berekenden Gill et al. (1989) een toename van de bijdrage van het maagdarmkanaal aan het totale energieverbruik voor ion-transport in het lichaam van 39 naar 50\% met een toename van de groeisnelheid, en een toename van de bijdrage van de lever van 18 naar $23 \%$.

In Tabel 1 zijn de cijfers voor uitsluitend droogstaand en lacterend melkvee nog eens opgesomd wat betreft aandeel van organen in de onderhoudsbehoefte, het aandeel daarin dat actief ion-transport voor haar rekening neemt, het (grof) geschatte aandeel van de totale bloeduitstroom via organen en het karkas, en het aandeel van de organen in het leeg gewicht.

Tabel 1 Globale weergave van huidige inschatting voor de bijdrage (in \%) van 1) het metabolisme van viscerale organen, 2) van het ion-transport aan de energetische onderhoudsbehoefte in een orgaan, 3) het aandeel dat het orgaan heeft in de totale bloeduitstroom vanuit het hart, en 4) het aandeel van het orgaan in het leeg lichaamsgewicht hoeveelheid van een melkkoe.

\begin{tabular}{|c|c|c|c|c|}
\hline & $\begin{array}{l}\% \text { energetische } \\
\text { Onderhoudsbehoefte }{ }^{1}\end{array}$ & $\begin{array}{l}\% \text { bijdrage ion-transport } \\
\text { in totale energieverbruik } \\
\text { orgaan }\end{array}$ & $\begin{array}{l}\text { uitstroom orgaan } \\
\% \text { uitstroom hart }{ }^{2}\end{array}$ & $\%$ BW \\
\hline \multicolumn{5}{|l|}{ Droogstand } \\
\hline Lever & 23 & 38 & 24 & 1.4 \\
\hline Maagdarmkanaal & 7 & 35 & 21 & 4.1 \\
\hline Nieren & 14 & 70 & 12 & 0.3 \\
\hline Uier $^{3}$ & 2 & $?$ & 10 & 2.0 \\
\hline Karkas & 26 & 5 & 33 & 62.5 \\
\hline \multicolumn{5}{|l|}{ Lactatie } \\
\hline Lever & 26 & 38 & 29 & 1.8 \\
\hline Maagdarmkanaal & 8 & 35 & 23 & 5.2 \\
\hline Nieren & 14 & 70 & 11 & 0.3 \\
\hline Uier & 4 & $?$ & 20 & 3.5 \\
\hline Karkas & 22 & 5 & 18 & 57.7 \\
\hline
\end{tabular}

$163 \mathrm{MJ} / d$ droogstaande koe; $69 \mathrm{MJ} / d$ lacterende koe

2 Aannames rondom doorbloeding lever en maagdarmkanaal gebaseerd op meta-analyse door Ellis et al. (2016) met gegevens voor vleesvee en lacterend melkvee; aannames rondom bloeduitstroom hart op basis van Baldwin (1995).

3 Het weergegeven \% betreft de bijdrage van het onderhoud van de uierweefsels aan de totale onderhoudsbehoefte.

Dit is dus exclusief de energiebehoefte voor melksynthese.

De cijfers in Tabel 1 geven aan dat de bijdrage van ion-transportmechanismen aan het in stand houden van de homeostase aanzienlijk is in de metabool meest actieve weefsels van het maagdarmkanaal en de lever. Ook is duidelijk dat deze organen relatief het meest doorbloed worden. Het ion-transport maakt dus een aanzienlijke post uitmaakt van het energieverbruik door deze weefsels en van het totale energieverbruik voor onderhoud van de melkkoe. Aangezien na afkalven de weefsels in het maagdarmkanaal en de lever ook nog eens een sterke groei, proliferatie en functionele aanpassing doormaken vanwege de snelle toename van de voeropname, neemt het aandeel dat deze weefsels innemen in de totale energetische onderhoudsbehoefte van de melkkoe verder toe (Tabel 1). Groei en functionele aanpassing ten behoeve van een hogere te bereiken orgaanactiviteit en een hogere 
verwerkingscapaciteit van nutriënten van de organen gaat gepaard met een extra investering in weefselgroei wat ook extra energetische kosten geeft. De energetische kosten voor onderhoud en de doorbloeding nemen toe bij stijging van de voeropname, toename van de orgaanmassa en toename van de melkproductie. Omdat het optreden van een acidose samengaat met een toename in ion-transport om deze acidose te compenseren of te verwerken, is het aannemelijk dat de zuur-base regulatiemechanismen in cellen, weefsels en organen en systemisch (in bloed) een significante invloed kunnen hebben op de energetische onderhoudsbehoefte van de melkkoe. Dit geldt met name voor de organen die wat betreft hun weefselmassa onevenredig sterk bijdragen aan het metabolisme en onderhoudsbehoefte van de koe: het maagdarmkanaal, de lever en de nieren (Tabel 1 ). 


\section{Acidose in de pens}

Op basis van de in hoofdstuk 2 opgesomde directe oorzakelijke factoren bij het ontstaan van een verzuring in een compartiment, is af te leiden dat met name een toename van de concentratie van vluchtige vetzuren en een afname van het concentratieoverschot aan sterke kationen ten opzichte van anionen (bijv. door een afname van de instroom aan kationen met speeksel of met voer) een verzuring van de pensinhoud kan geven. Hoewel ook andere factoren een rol spelen (de aanwezigheid van zwakke basen als fosforzuur/fosfaat en ammoniak/ammonium, de partiele gasdruk van kooldioxide in pensvloeistof, de concentratie aan kationuitwisselcapaciteit in de digesta, de concentratie aan bufferende eiwitten of mogelijk zelfs de microbiota; Bannink \& Dijkstra, 2006; Figuur 1), zijn de twee eerstgenoemde factoren het meest bepalend voor de $\mathrm{pH}$ van de vloeistof in de pens: de concentratie aan vluchtige vetzuren en het concentratieoverschot van sterke kationen ten opzichte van anionen. Melkzuur laten we hier buiten beschouwing. Een kleine piek in melkzuur kan tijdelijk waargenomen worden direct na een maaltijd, maar dit draagt weinig bij aan verzuring onder normale voedingsomstandigheden. Bij een werkelijke acute acidose kunnen hogere hoeveelheden melkzuur voor langere tijd aanwezig zijn en daarmee de $\mathrm{pH}$ beïnvloeden (Mills et al., 2014), maar (met uitzondering van graan-rijke rantsoenen) is deze klinische acidose veelal het gevolg van mismanagement.

\subsection{Productie en verdwijning van vluchtige vetzuren}

Vluchtige vetzuren kunnen in de pens ophopen indien de verplaatsing van de plaats van vorming naar de plaats van afvoer (de penswand) niet snel genoeg verloopt (Dieho, 2017). Hierbij speelt de motiliteit en de menging van de pensvloeistof een grote rol, en de daarmee samenhangende verplaatsing van de vluchtige vetzuren in de massa digesta in de pens.

Een ophoping kan eveneens optreden indien de capaciteit van de penswand om deze zuren te absorberen de snelheid van zuurvorming niet kan bijbenen. Hoewel het pensepitheel zich goed en snel kan aanpassen aan veranderde voedingsomstandigheden tijdens zowel de droogstand als de vroege lactatie (Dieho, 2017), vergt dit toch enige tijd; bovendien hoeft een toename van pensepitheel oppervlak niet automatisch gepaard te gaan met een hogere snelheid van absorptie van vluchtige vetzuren (Dieho, 2017). Daarmee kan een plotselinge, acute toename van de zuurvorming (bijv. ten gevolge van het niet gespreid voeren over de dag, het niet verdelen van de krachtvoergift over meerdere porties, of een plotselinge opname van een grote massa snel-fermenteerbare koolhydraten) alsnog tot een verzuring van de pensinhoud leiden. Alleen in extreme gevallen leidt dit tot de ontwikkeling van een acute acidose met een ophoping van melkzuur als mogelijk gevolg (Mills et al., 2014). Dit wordt dikwijls gerapporteerd voor herkauwers die voornamelijk met graan gevoerd worden, zoals vleesvee. Melkvee wordt meer gespreid over de dag gevoerd en neemt het voer meer gespreid op. Het aangeboden rantsoen bestaat bovendien voor een groot deel uit ruwvoer met een hoog kationgehalte (grasproducten), en indien dit voldoende structuurwaarde heeft dan vindt de opname geleidelijk plaats. Onder deze omstandigheden is het onwaarschijnlijk dat er een acute ophoping van zuren optreedt of dat er sprake is van een langdurige en sterke verzuring van de pensinhoud. Mogelijk dat onvoldoende menging van de pensinhoud, en als gevolg daarvan een te trage verplaatsing en transport van zuren in de pensinhoud, lokaal tot een verzuring kan leiden.

\subsection{Productie en verdwijning van melkzuur}

Bij een hoge zuurgraad kan de microbiota die melkzuur verbruikt (met name Megasphaera elsdenii) verdwijnen of inactief worden (Mills et al., 2014). Melkzuur ontstaat met name tijdens een hoge snelheid van organische stoffermentatie, zoals na een (of meerdere opeenvolgende) forse maaltijden met veel snel-fermenteerbare koolhydraten. Indien de capaciteit om dit melkzuur te verbruiken verdwijnt, dan kan het melkzuur zich ophopen in de pens waardoor de zuurgraad verder toeneemt en de melkzuurverbruikende microbiota verder geremd wordt, met als gevolg dat er steeds meer melkzuur 
gevormd wordt. Dit kan leiden tot de overgang van een subklinische pensacidose naar een acute pensacidose of melkzuuracidose. Mills et al. (2014) hebben de achtergronden van melkzuurophoping in de pens gemodelleerd, om de relatie te kunnen leggen tussen voeding en het ontstaan van de situatie van een melkzuuracidose. Wat een dergelijke acidose vooral klinisch maakt is dat het melkzuur evenals de vluchtige vetzuren snel wordt geabsorbeerd door de penswand waardoor de melkzuurconcentratie in bloed toeneemt en de zuurgraad van bloed daalt met als gevolg een metabole acidose. Onvoldoende regulatievermogen om deze metabole verzuring ten gevolge van melkzuur te compenseren kan in extreme gevallen leiden tot plotselinge sterfte bij rundvee. Melkzuur wordt normaal gesproken vooral gevormd in de eerste uren na de opname van een grote maaltijd die zich kenmerkt door een hoge snelheid van organische stoffermentatie (Van Lingen, 2017). Normaal gesproken is de ophoping van melkzuur echter slechts van zeer tijdelijke aard omdat het gevormde melkzuur ook meteen weer wordt verbruikt door de microbiota in de pens en er minder melkzuur gevormd wordt in de latere fase waarin de fermentatiesnelheid weer afgenomen is. Van Lingen (2017) vond slechts geringe hoeveelheden melkzuur na de ochtendmaaltijd, met op 1 uur na voeren een maximum aandeel in de totale hoeveelheid zuren (vluchtige vetzuren plus melkzuur) van slechts $2 \%$ en nagenoeg geen melkzuur meer op 3 uur na voeren. Hoewel kuilvoer een forse hoeveelheid melkzuur kan bevatten, zal dit melkzuur met een gunstige zuurgraad in de pens (en afwezigheid van een pensacidose) dan ook zeer snel verbruikt worden en niet van belang zijn voor het verzuren van de pensinhoud zoals dat veroorzaakt wordt door de ophoping van vluchtige vetzuren. Hoewel melkzuur een lagere pKa waarde heeft dan de vluchtige vetzuren is de gangbare $\mathrm{pH}$ waarde van pensvocht een stuk hoger en dus zullen zowel melkzuur als vluchtige vetzuren hoofdzakelijk in gedissocieerde vorm aanwezig zijn en is hun concentratie het meest bepalend voor het verzurende effect, niet zozeer de aard van het zuur. Mogelijk dat het met voer opgenomen melkzuur, wat in de pens omgezet wordt in vluchtige vetzuren, wel een ander profiel aan vluchtige vetzuren tot gevolg heeft, met relatief meer propionzuur ten koste van azijnzuur. Dit maakt voor de zuurgraad van de pensinhoud echter geen verschil omdat beide zuren een nagenoeg gelijke pKa waarde hebben. Opnieuw is de totale concentratie van deze zuren het meest bepalend voor de mate van verzuring en niet de aard van het zuur.

\subsection{Afvoer zuur met vloeistofpassage}

De speekselproductie en wateropname, en de daaraan gerelateerde vloeistofuitstroom, zijn eveneens een belangrijk mechanisme voor het verwijderen van de zuren uit de pens. Onvoldoende speekselproductie kan bijdragen aan een afname van de vloeistofinstroom en -passage (met de daarin opgeloste zuren) en een verzuring geven van de pensinhoud. Hoewel er bij een toename van de zuurconcentratie in de pens middels een osmotische werking direct een transport van water van bloed naar de pensinhoud optreedt (Lopez et al., 2003; Gregorini et al. 2015), kan het zijn dat door watergebrek (vanwege overmatig waterverlies met zweten, een hoge waterexcretie met feces of met urine in geval van een hoge zoutopname (Spek et al., 2012), of een verlaagde wateropname) dit watertransport onvoldoende bijdraagt aan de vloeistofturnover en de uitstroom van de in vloeistof opgeloste zuren.

Beauchemin et al. (2008) onderzochten het effect van voeders op de speekselproductie, en vonden dat het verlengen/vergroten van ruwvoerdeeltjes geen effect had op de speekselproductie in totaal, maar dat het voer wel langzamer werd opgenomen zodat zich per eenheden gevreten voer meer speeksel met dit voer mengde. De aard van het ruwvoer, het vochtgehalte van het rantsoen en het aandeel ruwvoer en krachtvoer in het rantsoen, en de voerstrategie beïnvloeden de snelheid waarmee de droge stof wordt opgenomen door de koe, en de mate waarin dit voer gemengd met speeksel in de pens komt. Voermaatregelen die de kauwactiviteit en herkauwen verhogen lijken een effectief middel om zo snel en zo goed mogelijk de pensinhoud te laten bufferen door geproduceerd speeksel. Dieho (2017) toonde aan dat het transport in de pens en de verdwijning van vluchtige vetzuren uit de pens vertraagd wordt door de aanwezigheid van de digesta massa zelf. Onderzoeksresultaten impliceren dat de aard van de digesta onder invloed staat van het aandeel ruwvoer in het rantsoen, van de ruwvoereigenschappen en de gevolgde voerstrategie, en dat dit mede van invloed is op de snelheid waarmee speeksel (met een sterk positieve balans van sterke kation en anionen) zich mengt met het voer dat in de digesta terecht komt, en op de snelheid waarmee de in de pens gevormde vluchtige vetzuren zich verplaatsen richting penswand om geabsorbeerd te worden naar het bloed.

De impact van speekselproductie op het algehele functioneren van de pens is groot zoals geconcludeerd door Bannink et al. (2016) op basis van bevindingen van Maekawa et al. (2002), Lopez et al. (2003) en 
Spek et al. (2012). Maekawa et al. (2002) maten speekselproducties van 250 liter per dag in melkvee met een voeropname van 17-18 kg droge stof per dag. Met een waargenomen vloeistofvolume van 80 liter betekent dit dat enkel de speekselinstroom al een turnover van pensvloeistof geeft van meer dan $300 \%$ per dag. De speekselproductie lijkt daarmee (onder normale omstandigheden, en bij een normale wateropname) verreweg de belangrijkste bijdrage te leveren aan de vloeistofuitstroom in de pens. De samenstelling van het rantsoen is een belangrijke factor voor de snelheid van vloeistofuitstroom. Zo'n 20 tot $40 \%$ van alle vluchtige vetzuren gevormd in de pens van melkvee worden niet door de penswand geabsorbeerd, maar verlaten de pens met de vloeistof die naar de boekmaag stroomt (Dijkstra et al., 2012). De vloeistofuitstroomsnelheid, en daarmee de uitstroom van vluchtige vetzuren, neemt toe met voeropname en met aandeel ruwvoer in het rantsoen.

\subsection{Bufferen via het rantsoen}

Een verzuring van de pensinhoud kan tegengegaan worden door (vergelijkbaar aan speeksel) een overschot aan kationen aan te leggen in het rantsoen. Dit kan door een keuze voor ruwvoer met een hoog gehalte aan natrium en/of kaliumgehalte (effectiviteit per mol ionen is identiek, afgezien van verschillen in verblijftijd van deze ionen in de pens) en een laag gehalte aan chloor en zwavel. Ook is het mogelijk om zouten te voeren met een overschot aan sterke kationen zoals bijvoorbeeld natriumbicarbonaat. Zouten die gevoerd worden tijdens de droogstand (droogstandsmineralen) hebben juist een tegenovergesteld effect met een relatief hoger aandeel sterke anionen in het rantsoen, en een (relatief) verzurend effect op de pensinhoud. Apper-Bossard et al. (2010) toonden aan dat op laagkrachtvoer rantsoenen zowel de $\mathrm{pH}$ van pensvloeistof als de $\mathrm{pH}$ van bloed resp. 0.2 en 0.03 eenheid hoger waren met een $300 \mathrm{meq} / \mathrm{kg}$ hoger kation-anion concentratieverschil in voer drogestof. Bij het hoogkrachtvoer rantsoen steeg de bloed $\mathrm{pH}$ met 0.08 eenheid maar bleef de $\mathrm{pH}$ van pensvloeistof gelijk. Afwezigheid van een stijging van de $\mathrm{pH}$ in de pens bij de hoog-krachtvoer behandelingen lijkt veroorzaakt door een compenserend verzurend effect van een $10 \mathrm{mM}$ hogere concentratie aan vluchtige vetzuren (wat bij het laag-krachtvoerrantsoen slechts $4 \mathrm{mM}$ was).

Ten slotte, kan in principe ieder bestanddeel in het rantsoen dat kationen kan uitwisselen met protonen in de pensvloeistof een bufferende uitwerking hebben op het verzurende effect van de gevormde vluchtige vetzuren. Hoewel deze bufferende capaciteit bekend is voor met name ruwvoeders als vers gras, grassilage en leguminosen (Giger-Riverdin et al., 2002), is er veel minder informatie over de mate waarin dit een bijdraagt aan de buffering van de pensinhoud in vivo met de huidige melkveerantsoenen. Ook andere bestanddelen die de capaciteit hebben om kationen uit te wisselen zullen in principe een dergelijke uitwerking. Een belangrijk aandachtspunt hierbij is bij welke $\mathrm{pH}$-waarde van pensvocht deze kationuitwisseling optreedt. Als deze kritische $\mathrm{pH}$-waarde boven de 7 ligt dan zal het bestanddeel de kationen uitwisselen met de pensinhoud. Dan kan het vergeleken worden met het voeren van een bufferend zout als natriumbicarbonaat, wat eveneens altijd dissocieert in een vochtige omgeving zoals in een gemengd rantsoen en/of pensvocht. Als de kritische $\mathrm{pH}$ waarde ver beneden de 6 ligt dan zal het bestanddeel de bufferende werking maximaal uitoefenen bij een $\mathrm{pH}$ van pensvocht ver beneden de 6 , en in geringe mate bij een $\mathrm{pH}$ tussen de 6 en 7. Voor een verdere uitleg van de werkingsmechanismen van het zuur-base evenwicht in de pens wordt verwezen naar Bannink \& Dijksta (2006).

\subsection{De gevolgen van pensverzuring}

De algemene veronderstelling is dat beneden een $\mathrm{pH}$ van 6.3 de activiteit van fibrolytische microorganismen geremd wordt. Dit heeft een lagere celwandvertering in de pens tot gevolg. Indien deze daling niet gecompenseerd wordt door een toename van de vertering van de pensuitstroom aan potentieel verteerbare celwanden in de dikke darm, zal ook de fecale celwandvertering afnemen en daarmee de totale verteerbaarheid van het rantsoen. Naarmate de $\mathrm{pH}$ in de pens verder daalt neemt ook de verteerbaarheid van het rantsoen af en neemt de nutriënten beschikbaarheid voor de melkkoe af. Klassiek onderzoek door Robinson et al. (1986, 1987a, 1987b) laat zien dat met een toename van de voeropname van 6 naar $24 \mathrm{~kg}$ droge stof per dag met een identiek rantsoen (1/3 lang hooi, 2/3 krachtvoer pellets) de gemiddelde $\mathrm{pH}$ in de pens daalt van 6.6 naar 6.0 , het aantal uren gedurende de dag dat de $\mathrm{pH}$ zich beneden de 6.0 bevindt stijgt van 0 naar 12 uur per dag, de ratio van bacteriële organische stof en celwanden in de digesta in de pens daalt van 0.55 naar 0.31 , de afbraaksnelheid van NDF daalt van 
4.0\%/uur naar $2.5 \% /$ uur, de fecale verteerbaarheid van organische stof daalt van $75.8 \%$ naar $68.0 \%$ en die van celwanden van $70.3 \%$ naar $56.6 \%$. Hoewel de aard van het rantsoen sterk afwijkt van de melkveevoeding in de huidige praktijk maken deze experimenten zonder een verstrengeling met andere voedingsfactoren inzichtelijk wat de invloed van voeropname is. Uit de resultaten blijkt duidelijk een remmende werking van de omstandigheden in de pens die samengaan met een verlaagde $\mathrm{pH}$ in de pens.

Robinson et al. (1986, 1987a, 1987b) hebben de verschillende voeropnames gerealiseerd in verschillende lactatiestadia. Echter, ook binnen een lactatiestadium kan een verzuring van de pensinhoud en afgenomen celwandafbraaksnelheid ook een hogere retentietijd tot gevolg hebben, en een daardoor grotere vulling van de pens, met als gevolg een daling van de voeropname. Een pensverzuring tijdens de lactatiestart kan ofwel een verminderde vertering van het rantsoen tot gevolg kan hebben, ofwel een verlaagde voeropname. Beide maken dat de melkkoeien minder energie opnemen dan berekend op basis van hun potentiele voederwaarde en verzadigingscapaciteit. Dit is in principe onwenselijk, met name voor een hoogproductieve melkkoe in een negatieve energiebalans.

Een ander gevolg van een ophoping van zuren in de pensinhoud is een mogelijk schadelijke uitwerking op de microbiota in de pens. Indien een deel van de microbiota afsterft dan ontstaan uiteenlopende endotoxinen die de weefsels van de melkkoe als lichaamsvreemd aanmerken. Lipopolysacchariden als afbraakproduct van gram-negatieve bacteriën in de pens zijn het best onderzocht. Deze kunnen zich door de penswand bewegen naar het bloed waar ze als lichaamsvreemde stof een immuunrespons veroorzaken. Deze immuunrespons treedt op systemisch niveau op (en mogelijk ook al in de maagdarmwand). Het is onduidelijk in hoeverre de functionaliteit van de penswand direct door deze immuunrespons beïnvloed wordt. Zhang et al. (2016) toonden een duidelijk upregulatie aan van ontsteking-gerelateerde genen in pensepitheel van melkkoeien met een hoog-krachtvoer rantsoen ( $70 \%$ krachtvoer, $12 \%$ alfalfa, $4 \%$ stro en $10 \%$ maissilage op droge stof basis) vergeleken met een laagkrachtvoerrantsoen ( $40 \%$ krachtvoer, $27 \%$ alfalfa en $30 \%$ maissilage op drogestof basis). Deze studie is echter in een cross-over design uitgevoerd op 84 dagen in lactatie met slechts 4 Holstein koeien met een lichaamsgewicht van gemiddeld $460 \mathrm{~kg}$. Bovendien werden de koeien voorafgaand aan het experiment 3 weken lang met een krachtvoerarmer rantsoen gevoerd (30\% krachtvoer op drogestof basis). De behandelingen werden getoetst met een 11-daagse aanpassingsperiode en een 10-daagse meetperiode. De hoog-krachtvoer behandeling had vergeleken met de laag-krachtvoerbehandeling een hogere concentratie aan vluchtige vetzuren (125 vs. $111 \mathrm{mM}$ ) en een hogere concentratie melkzuur (0.24 vs. $0.18 \mathrm{mM}$ ), een lagere $\mathrm{pH}$ waarde (vreemd genoeg geen numerieke gegevens gerapporteerd), en een hoger gehalte aan lipopolysacchariden (26.3 vs. $14.7 \mathrm{kEU} / \mathrm{ml})$.

De vraag blijft echter of dergelijke effecten ook te verwachten zijn voor rantsoenen met een hoog aandeel ruwvoer, en dan met name gras(silage), omdat de door Zhang et al. (2016) gekozen behandelingen eerder een diermodel lijken om acidose op te wekken dan een weergave van de huidige praktijk van melkveevoeding in Nederland. In het recente promotieonderzoek van Dieho (2017) werden voor twee contrasterende opbouwschema's na afkalven met behulp van macroscopie/histologie geen aanwijzingen gevonden voor verschillen in (afwijkingen van) penspapillen (zoals bijv. de aanwezigheid van ontstekingen in de epitheellaag). Dit lijkt er op te duiden dat alleen bij opname van grote hoeveelheden snel-fermenteerbare koolhydraten, zoals met de opname van granen in rantsoenen voor vleesvee, er epitheelschade kan optreden vanwege zeer lage $\mathrm{pH}$ waarden die bereikt worden en in de buurt liggen van de pKa waarde van de vluchtige vetzuren (rondom 5). Bij dergelijk lage pH waarden is een substantieel deel van de zuren in ongedissocieerde vorm in pensvocht aanwezig en kan direct middels passieve diffusie binnentreden in de pensepitheellaag (Dijkstra et al., 1993; Dijkstra et al., 2012), ongeacht of de verwerkingscapaciteit van de penswand voldoende is of niet. De epitheellaag zal zich afschermen van diffusie van grote hoeveelheden ongedissocieerd zuur middels keratinisering en een verlaging van de absorptiecapaciteit aan de mucosale zijde, of beschermen door een intracellulaire ophoping en verhoogd metabolisme van deze zuren, of door middel van een versnelde afvoer via bloed aan de serosale zijde (verhoogde doorbloeding). Bij sommige van deze aanpassingen wordt het absorptieoppervlak en/of de absorptiecapaciteit van papillen negatief beïnvloed, wat op haar beurt weer bijdraagt aan een ophoping van zuren in de pens. Bij verdergaande verzuring van de pensinhoud neemt het microbiële verbruik van melkzuur af en kan ook dit zuur zich ophopen en geabsorbeerd worden. In onderzoek van Dieho (2017) werden echter geen aanwijzingen gevonden voor een verhoogde keratinisering of andere aanpassingen in het epitheel. 
Hoewel onduidelijk is wat de consequenties zijn van een upregulering van genen in pensepitheel die betrokken zijn bij ontstekingsreacties (functionele metingen ontbreken dikwijls in dit type onderzoek), ligt het voor de hand om te veronderstellen dat de mogelijke metabole consequenties voor het weefsel groot zijn. Aanzienlijke energetische kosten gaan gepaard met een immuunrespons, en er is waarschijnlijk eveneens een groot verbruik van aminozuren. Deze energetische en eiwitkosten kunnen mogelijk (tijdelijk) concurreren met de energetische en eiwitkosten van een aanpassing en proliferatie van het epitheel aan een veranderde voersituatie, zoals een verhoogde opname van krachtvoer in de periode na afkalven. Indien de immuunrespons ten koste gaat van de beschikbare energie en eiwit voor een voldoende snelle aanpassing van het pensepitheel, dan blijft de verwerkingscapaciteit van het pensepitheel voor vluchtige vetzuren mogelijk achter bij het aanbod. Het achterblijven van de absorptiecapaciteit is dan mogelijk op zichzelf een aanleiding voor ophoping van zuur en een lage $\mathrm{pH}$ in de pens. Anderzijds, indien de aanpassing van het pensepitheel ten koste gaat van de immuunrespons, dan ontstaat er mogelijk eerder schade aan het epitheel (ontstekingen, lesies, keratinisering). Dit laatste wordt echter voornamelijk gerapporteerd voor extreme voeromstandigheden die bedoeld zijn als poging om een pensacidose op te wekken, of die optreden bij vleesvee dat gevoerd wordt met een rantsoen dat een groot aandeel granen bevat. Abnormaliteiten in de penswand gevonden bij vleeskalveren die veel krachtvoer gevoerd kregen (Suarez et al., 2006) zijn mogelijk eerder veroorzaakt door de afwezigheid van ruwvoer dan door de $\mathrm{pH}$ of de concentratie vluchtige vetzuren. Ruwvoer voorkomt de vorming van zogeheten plaques en schraapt als het ware de penswand schoon. Deze waargenomen abnormaliteiten betreffen de ontwikkeling van de pens in het juveniele dier, en zijn daarmee niet representatief voor een reeds volledig ontwikkelde pens in een adulte melkkoe.

Dionnosopoulos et al. (2013) bestudeerden het effect van boterzuur toevoeging aan het pensmilieu op de genexpressies in pensepitheelcellen. Zij concludeerden uit hun resultaten dat exogeen boterzuur de aanpassing van het epitheel aan een verzurend rantsoen bevordert en de expressie van inflammatoire genen, de hoeveelheid lipopolysacchariden in de pens en lipopolysaccharide-binding-protein in bloedplasma vermindert. Er werd echter geen behandeling met toevoeging van een van de andere vluchtige vetzuren uitgevoerd.

Ook worden een verminderde structurele samenhang van de cellen in de epitheellaag (verstoring van de tight junctions tussen de epitheelcellen) en een verhoogde permeabiliteit van de epitheellaag gemeld als verstorende invloed van een hoog-krachtvoer rantsoen (en eventuele challenge van het epitheel met lipopolysacchariden). De rantsoenen die gehanteerd worden om een acidose op te wekken zijn echter extreem ten opzichte van huidige praktijkrantsoenen voor melkvee (bijv. 65\% graan op droge stof basis in een rantsoen voor geiten, Liu et al., 2013). Penner \& Beauchemin (2010) hebben schematisch weergegeven bij welk type rantsoenen en $\mathrm{pH}$ waarden in de pens negatieve effecten of schade aan het epitheel wordt waargenomen (Figuur 2). Hieruit blijkt dat dit pas te verwachten is bij zeer lage $\mathrm{pH}$ waarden beneden de 5.5. Dergelijk lage waarden gaan doorgaans samen met rantsoenen met een laag aandeel ruwvoer, een hoog aandeel granen, en een hoog aandeel snel-fermenteerbare koolhydraten in de rantsoen droge stof. Jing et al. (2014) voerden een interessant experiment uit met melkvee om het effect van lipopolysacchariden op het pensepitheel te testen. Ze voerden een rantsoen wat niet tot een verzuring van de pensinhoud leidde $(\mathrm{pH}$ 6.5) en geen aanleiding gaf tot de vorming van lipopolysacchariden. In plaats daarvan werden lipopolysacchariden intraveneus ingebracht en metingen werden verricht in de pens die aantoonden dat met een toename van infuus van lipopolysacchariden de $\mathrm{pH}$ in de pens daalde, de concentratie vluchtige vetzuren toenam, de samenstelling van de microbiota veranderde, de microbiële activiteit afnam, en de verteerbaarheid van het rantsoen afnam. Hoewel slechts 3 melkkoeien werden gebruikt, had het experiment een goede opzet volgens een volledig $3 \times 3$ Latijns vierkant en er was een negatieve controle voor het intraveneuze infuus opgenomen in de opzet.

Onderzoeksresultaten lijken dus aan te geven dat lipopolysacchariden die in de bloedbaan komen vanwege een disfunctioneren van de pens met een sterk verzuurd pensmilieu, de verwerkingscapaciteit van de penswand voor vluchtige vetzuurtransport doet afnemen, wat het disfunctioneren van de pens verergert. Hoewel het effect van systemische lipopolysacchariden en van lipopolysacchariden die vrijkomen in de pens moeilijk van elkaar te onderscheiden zijn, geven experimenten duidelijke indicaties voor de mogelijkheid van een negatieve uitwerking op het functioneren van het pensepitheel. Hoe deze negatieve uitwerking tot stand, en of dit een direct effect is (bijv. een verminderde of een geremde metabole capaciteit van pensepitheel), of een indirect effect (bijv. een verminderde doorbloeding van pensepitheel, of schade aan het epitheel), is niet duidelijk. Zo werden er door Jing et al. (2014) geen effecten gevonden op de genexpressie van $\mathrm{Na}$ /K-ATPase en monocarboxylic acid transporters-1, -2 en - 
4, wat een aanwijzing kan zijn dat niet de transportcapaciteit van cellen veranderde, maar dat er een lagere doorbloeding was van de pens vanwege een veranderde prioritering bij de verdeling van de bloedstroom over de verschillende organen bij de systemische immuunrespons opgewekt door de systemisch ingebrachte lipopolysacchariden. Recent bediscussieerde ook Dieho (2017) de mogelijkheid dat niet de ontwikkeling en aanpassingscapaciteit van penspapillen of het pensepitheelweefsel de beperkende factor is voor (aanpassing van) de capaciteit van vluchtige vetzuurtransport en -absorptie, maar een extra-epitheliale factor. De doorbloeding van het epitheel als factor lijkt het meest aannemelijk. Indien deze doorbloeding verstoord wordt door bijvoorbeeld het ontstaan van lipopolysacchariden in de pens, hun opname door het pensepitheelweefsel en hun verschijning in de bloedcirculatie van de melkkoe, dan zou dit kunnen bijdragen aan het ontstaan of verergeren van een reeds aanwezige pensverzuring. Onder normale omstandigheden is het niet te verwachten dat pensepitheel sterk doorlatend is voor lipopolysacchariden (Gareau et al., 2008; Plaizier et al., 2012). Echter, andere factoren worden genoemd, zoals stress (Gareau et al., 2008), waaraan ernstige consequenties voor het functioneren van het maagdarmkanaal worden toegeschreven, inclusief een veranderde permeabiliteit en effecten op iontransportmechanismen. Ook bij extreme voeromstandigheden, een sterk verzuurde pensinhoud en een mogelijk sterke belasting van het pensepitheel (zoals bijvoorbeeld met een hoog aandeel granen in het rantsoen) is dit mogelijk het geval. In dit opzicht zijn er vele mogelijke interacties denkbaar tussen de voeding, de microbiota in de pens, de vorming van vluchtige vetzuren en melkzuur, de beschikbare buffermechanismen voor de zuurgraad van de pensinhoud, de aanpassing van het pensepitheel (met inbegrip van indirecte factoren zoals de doorbloeding van het pensepitheel) en de fysiologische status en het immuunsysteem van de gastheer. De veelheid aan factoren en mogelijkheden voor het wel of niet aanwezig zijn van deze interacties draagt waarschijnlijk bij aan het probleem om oorzaken en gevolgen van elkaar te onderscheiden bij de diagnose van subklinische en/of klinische pensacidose. Als voorbeeld, een immuunrespons in het epitheel in de penswand is in principe aan te merken als een positieve reactie om de weefsels van de gastheer te beschermen tegen lichaamsvreemde stoffen en pathogenen. Maar indien een dergelijke immuunrespons tevens bijdraagt aan een verminderde buffering en een verergerde verzuring van de pensinhoud, een verzuring van de inhoud van de dikke darm, en zelfs een metabole verzuring kan geven, dan versterkt dit juist de oorzaak van de verzuring in plaats van het weg te nemen wat juist een negatieve uitwerking kan hebben op de vertering en het functioneren van de koe.

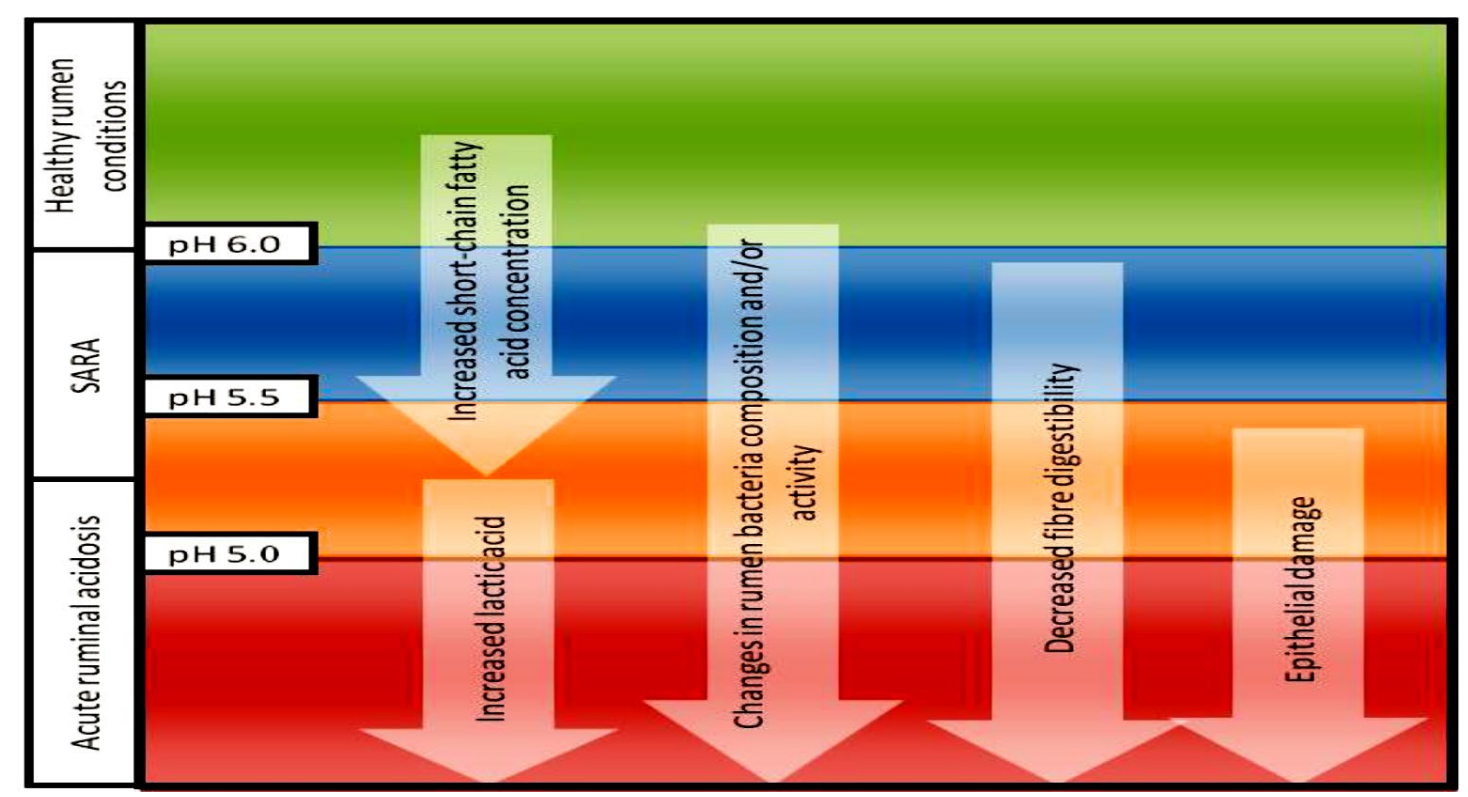

Figur 2 Schematische weergave van Penner \& Beauchemin (2010) voor de veronderstelde relatie tussen de mate van pensverzuring, de $\mathrm{pH}$ van de digesta in de pens, en de verandering in functionele penskenmerken, inclusief de microbiota en de status van het pensepitheel. 


\subsection{Opsomming interessante, te onderzoeken factoren}

Op basis van voorgaande zijn er verschillende aspecten te noemen van het fenomeen pensverzuring die interessant zijn om verder te onderzoeken:

- De invloed van andere factoren dan de hoeveelheid fermenteerbare organische stof (en vluchtige vetzuren die gevormd worden) op de $\mathrm{pH}$ in de pens. Bijvoorbeeld de invloed van de doorbloeding van pensepitheel op de mate waarin een pensverzuring opgewekt kan worden, de invloed van meer of minder structuur op de snelheid waarmee zuren afgevoerd worden, of de invloed van de kationuitwisselcapaciteit van uiteenlopende ruwvoeders op de buffercapaciteit van de pensinhoud.

- De functionaliteit van de penswand en de effectiviteit van buffermechanismen in de pens bij een sterk wisselende in plaats van een regelmatige voeropname, bij meer of minder structuur in het rantsoen (grotere of kleinere deeltjes), bij een droger of natter rantsoen, bij een hogere of lagere osmotische waarde van het rantsoen.

- Het maximale aanpassingsvermogen van pensepitheel en aanwezige buffermechanismen bij een extreme pensverzuring al dan niet in combinatie met beperkende factoren (doorbloeding, immuun challenge, energiegebrek tijdens vroege lactatie, e.d.).

- $\quad$ De invloed van een aangelegde pensverzuring op de integriteit van pensepitheel en de capaciteit aan iontransport, zuurtransport, barrière-functie (migratie micro-organismen, doorlaten endotoxinen zoals lipopolysaccharide, e.d.)

- $\quad$ Idem, voor de invloed van een systemische immuun challenge

- $\quad$ Idem, voor de invloed van een metabole acidose (bijv. ketose)

- Invloed van verhoogde wateropname (al dan niet verrijkt met kationen) om de turnover en uitstroom van pensvloeistof te bevorderen en pensverzuring te bufferen.

- Het aantonen van een onderscheid tussen de invloed van de $\mathrm{pH}$ van pensvloeistof, van de totale productiesnelheid van zuur en van het type zuur op de aanpassing van het pensepitheel en fermentatie (m.n. de fibrolytische activiteit). 


\section{$4 \quad$ Acidose in de dikke darm}

Vergelijkbaar aan de mechanismen in de pens, kunnen ook snel-fermenteerbare koolhydraten de dunne darm verlaten, de dikke darm instromen en daar gefermenteerd worden en een verzuring geven. Dit gebeurt voornamelijk met een hoog aandeel zetmeelrijke producten in het rantsoen waarvan het zetmeel deels bestendig is tegen afbraak in de pens, zoals maisproducten en natief aardappelzetmeel. Maar ook de in principe als minder bestendig bestempelde zetmeelrijke producten zoals granen, behandelde aardappelproducten en behandelde of geënsileerde maisproducten (CCM) kunnen door bij hoge passagesnelheden en een hoog aandeel in het rantsoen waarschijnlijk in de dikke darm terecht komen. Ook pectines kunnen deels ontsnappen aan fermentatie in de pens en kunnen de dikke darmfermentatie stimuleren zoals uit verteringsonderzoek met melkvee blijkt (Valk et al., 1990; Van Vuuren et al., 1993). Hierbij dient opgemerkt te worden dat een bepaald basisnivo van fermentatie in de dikke darm gebruikelijk is. Een deel van potentieel afbreekbaar vezel ontsnapt aan afbraak in de pens en kan vervolgens deels gefermenteerd worden in de dikke darm. Bijvoorbeeld, onder de aanname dat $15 \%$ van de totale vertering van vezel plaatst vindt in de dikke darm (en $85 \%$ in de pens), bij een totale NDF vertering van $75 \%$ en een NDF gehalte van $350 \mathrm{~g} / \mathrm{kg}$ DS, wordt er $40 \mathrm{~g} \mathrm{NDF} / \mathrm{kg}$ DS gefermenteerd in de dikke darm. Deze hoeveelheid van $40 \mathrm{~g} / \mathrm{kg}$ DS is ruwweg gelijk aan de hoeveelheid zetmeel die gefermenteerd wordt in de dikke darm bij een zetmeelgehalte van $400 \mathrm{~g} / \mathrm{kg}$ DS, een aandeel pensbestendig zetmeel van $30 \%$, en een aandeel van enzymatische vertering van pensbestendig zetmeel van $70 \%$ in de dunne darm. Dit rekenvoorbeeld geeft aan dat wellicht niet enkel de hoeveelheid fermenteerbare organische stof in de dikke darm (en daarmee de $\mathrm{pH}$ van de digesta in de dikke darm), maar wellicht meer het type organische stof te associëren is met problemen die veelal onder de term 'dikke darm acidose' geschaard worden. Dit is vergelijkbaar met een aanzienlijk groter probleem met LPS bij pensacidose veroorzaakt door snelle fermentatie van graan, versus pensacidose bij snelle vertering van alfalfa ( $\mathrm{Li}$ et al., 2012), waarbij de subacute pensacidose op het alfalfa rantsoen niet gepaard ging met LPS verhoging in de dikke darm inhoud, in tegenstelling tot het graanrantsoen waar LPS in dikke darm inhoud wel sterk toenam. De hoeveelheid zetmeel die wordt opgenomen heeft invloed op de hoeveelheid snel-fermenteerbare koolhydraten die de pens passeren en alsnog fermenteren in de dikke darm. Met name bij hoge voeropnames en mogelijk ook met de snelle stijging van de voeropname na afkalven en de daarmee geassocieerde stijging van de vloeistof- en deeltjespassage, kan de fermentatie in de dikke darm sterk toenemen. Een verhoogde instroom van fermenteerbare organische stof geeft een toename van de productie en absorptie van vluchtige vetzuren. Omdat een deel van deze zuren niet op tijd geabsorbeerd wordt en (dus) wordt uitgescheiden met feces, leidt een verhoogde fermentatie tot een verlaging van de $\mathrm{pH}$ waarde van verse feces (Dijkstra et al., 2012). Dit is anders dan bij de pens waar vluchtige vetzuren die met de vloeistof uit de pens stromen, alsnog volledig geabsorbeerd worden in het abomasum waarvan de inhoud een zeer lage $\mathrm{pH}$ waarde heeft vanwege de secretie van zoutzuur (vergelijkbaar aan de maag bij éénmagigen). Om deze reden stromen er nauwelijks vluchtige vetzuren uit naar het duodenum. Bovendien ontbreekt het in de dikke darm aan een instroom van buffer, in tegenstelling tot de instroom van speeksel in de pens. Dikke darm-verzuring is geassocieerd met een lage zuurtegraad van de verse feces (omdat een deel van de vluchtige vetzuren niet geabsorbeerd wordt voordat de verse feces wordt uitgescheiden; Dijkstra et al., 2012), inconsistente mest (bijv. diarree) en aantasting of afscherming van het darmepitheel (slijmerige mest), wat vervolgens tot ontstekingen en laminitis (d.w.z. klauwbevangenheid) kan leiden (Gressley et al., 2011). 


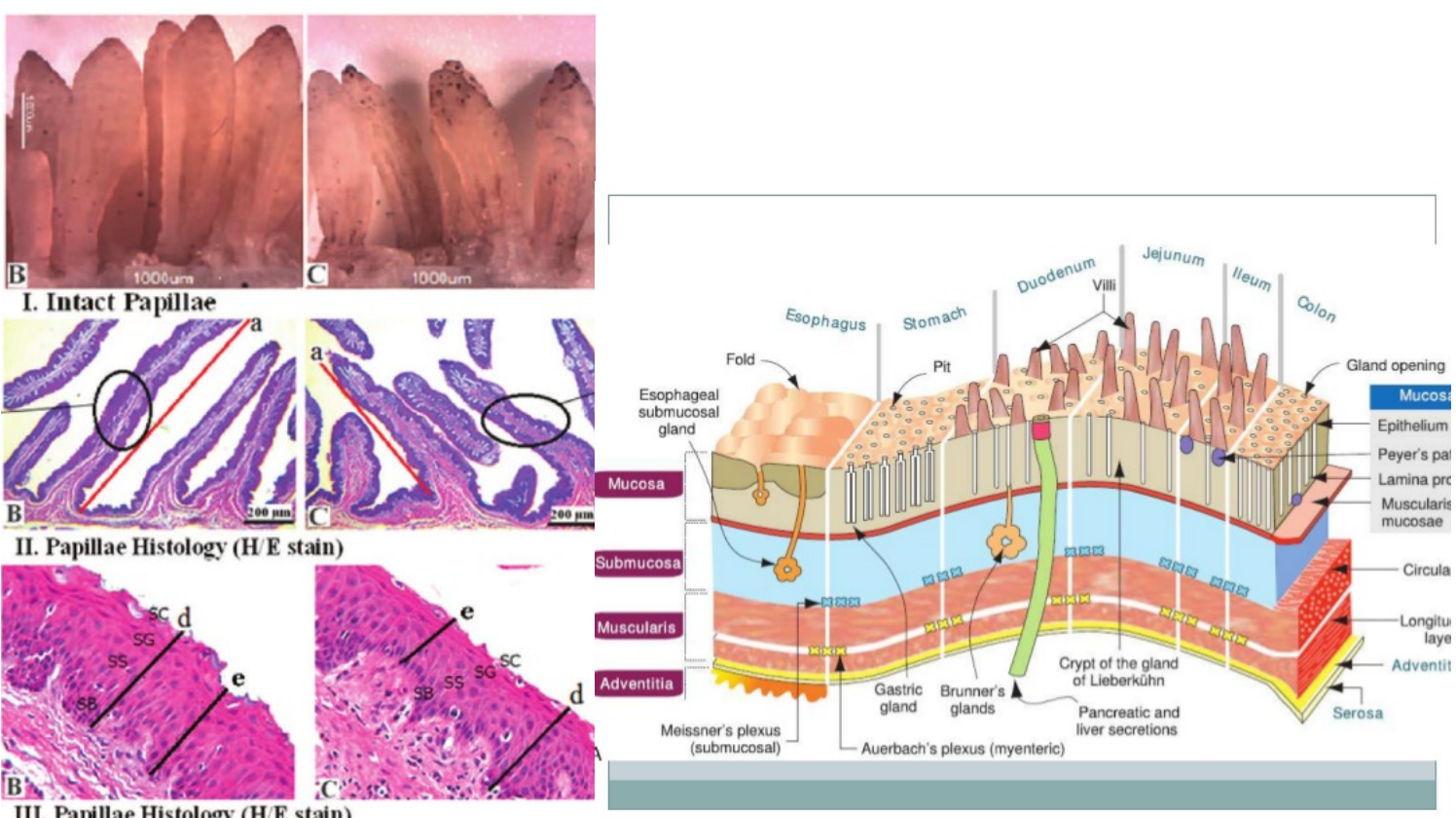

Figuur 3 Schematisch overzicht van de verschillen in epitheel in verschillende compartimenten van het maagdarmkanaal (links, pensepitheel; rechts, epitheel in de compartimenten van het maagdarmkanaal waarbij de pens/netmaag/boekmaag als voormagen ontbreken). (bron: https://www.researchgate.net/figure/ 257752857_fig2_Figure-2-Micrographs-I-showinglength-and-width-of-rumen-papillae-histomicrographs)

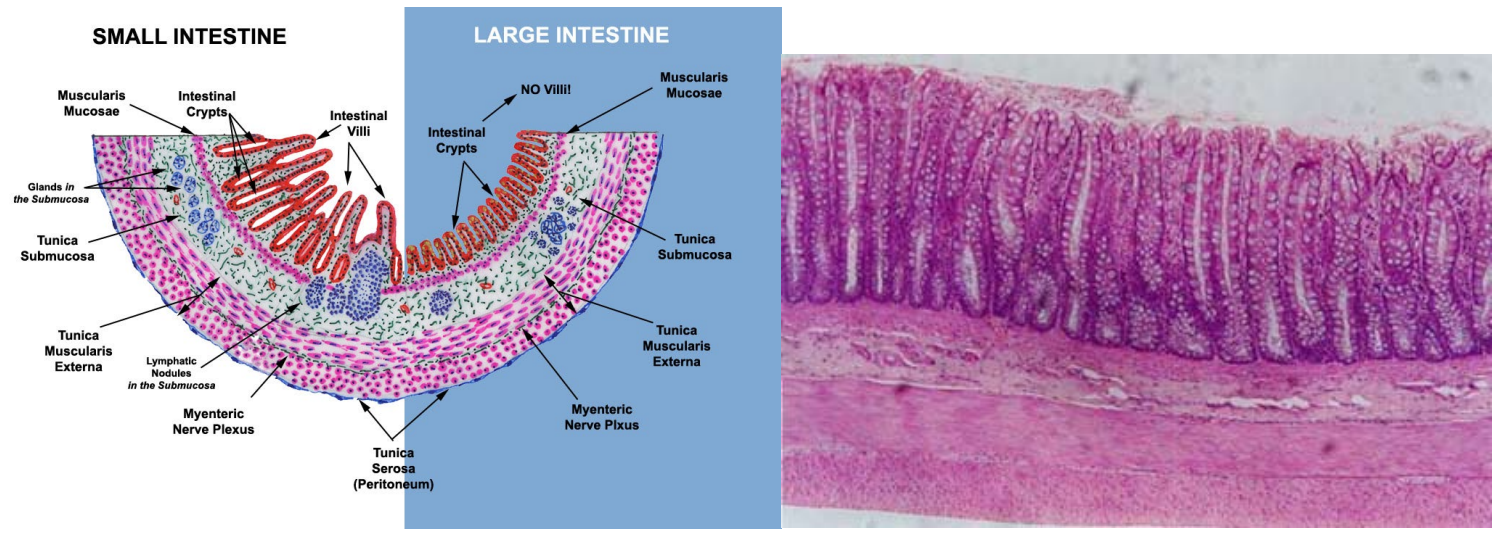

Figuur 4 Verschillen tussen epitheel in de dunne darm en dikke darm (links) en een histologische opname van colonepitheel (rechts) waarin zich veel Goblet-cellen bevinden die mucus aanmaken. (bron: http://www.doctorc.net/Labs/Lab19/Lab19.htm)

\subsection{Water- en elektrolytenbalans}

Een verhoogde concentratie van vluchtige vetzuren geeft een hogere osmotische waarde van de digesta, vergelijkbaar aan de pens waar de instroom van systemisch water via de penswand erg groot kan zijn (Dieho, 2017). Dit kan tot gevolg hebben dat water wordt aangetrokken en dat veel water met de feces wordt uitgescheiden. Indien de zuurgraad in de dikke darm gereguleerd wordt dan gaat dit (net als met de kationen die met speeksel in de pens komen) wellicht door middel van ion-transportmechanismen in de darmwand en daarmee het inbrengen van kationen in de digesta. Dit kan een verhoogde excretie van kationen met de feces tot gevolg hebben. Dit verlies aan kationen is afkomstig uit systemisch bloed en het verlies kan daarmee bijdragen aan een verlaging van het kationgehalte in bloed en de kation-status van de melkkoe. Een vermindering van kationen in bloed kan dan bijdragen aan het ontstaan van een metabole verzuring. In de literatuur is hierover echter weinig informatie te vinden. Bovendien, normaal gesproken is er een overschot aan kationen beschikbaar vanuit het voer die in het maagdarmkanaal geabsorbeerd wordt, en door de nieren met urine uitgescheiden (Bannink et al., 1999). Een verlies aan kationen met de feces is eenvoudig te compenseren door de nieren door middel van een verlaagde excretie met de urine. Dit ligt mogelijk anders voor een rantsoen dat uit zichzelf al een laag kationgehalte 
heeft, zoals met een rantsoen met vooral snijmais als ruwvoer, of in het geval er gelijktijdig een ander groot verlies aan elektrolyten optreedt (zoals bijv. door zweten en hittestress tijdens de zomer, of bij diarree opgewekt door een infectie met een pathogeen). Een aandachtspunt is dat deze verliezen bij een rantsoen met een zeer laag kationgehalte de melkkoe in een negatieve kationbalans kan brengen met als gevolg een metabole acidose en bijbehorende fysiologische verschijnselen. Dergelijke waarnemingen zijn gedaan (Bannink et al., 1999). Tevens kan dit optreden met een negatieve energiebalans tijdens de vroege lactatie en een gelijktijdig hoge excretie van kationen met de melk.

\subsection{De $\mathrm{pH}$ van digesta in de dikke darm, lipopolysacchariden en dikke darmepitheel}

Vanwege de geheel andere ontogenetische herkomst en andere structuur dan pensepitheel is het epitheel van de dikke darm (Figuur 3) mogelijk minder goed toegerust om zich aan te passen aan een sterk verhoogde snelheid van fermentatie (van m.n. zetmeel en pectines) en excessieve zuurvorming (Figuur 4). Opwekking van een acidose in de dikke darm kan aanleiding geven tot beschadigingen van de epitheellaag. Ook mist de bufferende uitwerking van protozoen, die in de pensdigesta een aanzienlijk deel uitmaken van de microbiota, maar niet aanwezig zijn in de digesta in de dikke darm. Protozoën kunnen bij een sterk verhoogd aanbod aan snel-fermenteerbare koolhydraten deze tijdelijk opslaan om later alsnog verbruikt te worden als energiebron. In de pens hebben protozoën met deze opslagfunctie een nivellerende uitwerking op de verdeling van de organische stof fermentatie over de dag. In de dikke darm ontbreekt dit mechanisme vanwege het ontbreken van protozoën.

Tao et al. (2014) vonden in geiten op een krachtvoerrijk rantsoen een significante hoger gehalte aan lipopolysacchariden in de pens vergeleken met geiten op een krachtvoerarm rantsoen, maar niet in bloedplasma. Enkel op het krachtvoerrijke rantsoen werd eveneens een verstoring van de structuur aan de mucosale zijde van het epitheel in zowel het caecum als het colon waargenomen. Terwijl activatie van apoptose en ontstekingsreacties samengingen met de waargenomen schade aan het epitheel in het colon, leek vooral activatie van de apoptose de oorzaak in het caecum. Deze resultaten laten zien dat een pensverzurend rantsoen mogelijk ook een verzuring in de dikke darm veroorzaakt evenals een veranderde structuur en barrièrefunctie van het dikke darm epitheel. Ook Emmanuel et al. (2007) vonden bij een lage $\mathrm{pH}$ waarde van de digesta en de aanwezigheid van lipopolysacchariden dat zowel het pens- als het colonepitheel van vleesstieren meer permeabel werd. De translocatie van aanwezige lipopolysacchariden bleek onafhankelijk te zijn van $\mathrm{pH}$, waarmee de $\mathrm{pH}$ zelf niet de causale factor lijkt te zijn voor translocatie. Echter, dit onderzoek betrof in vitro onderzoek met Ussing kamers en hiervoor resteert altijd de vraag in hoeverre dergelijke resultaten kwantitatief vertaalbaar zijn naar de in vivo situatie, en of zij ook daadwerkelijk een indicatie zijn voor de permeabiliteit en het "lekken" van de epitheellaag van bestanddelen in de dikke darm digesta naar de bloedbaan van de melkkoe. Onderzoeksresultaten geven in het algemeen aan dat het voeren van grote hoeveelheden snel-fermenteerbare koolhydraten tot grotere hoeveelheden lipopolysacchariden leiden, en dat naast de pens ook de dikke darm hieraan kan bijdragen en onderhevig aan is. De translocatie van deze lipopolysacchariden naar systemisch bloed leidt vervolgens tot een sterke ontstekingsreactie bij de melkkoe (Emmanuel et al., 2008). Ook al zijn lipopolysacchariden geen pathogenen die na besmetting een verdergaande infectie en sepsis veroorzaken, het betreft wel lichaamsvreemde stoffen waarop het immuunsysteem sterk reageert.

\subsection{Opsomming interessante, te onderzoeken factoren}

Op basis van voorgaande zijn er verschillende aspecten rondom dikke darmverzuring die interessant zijn om verder te onderzoeken:

- De invloed van excessieve fermentatie in de dikke darm op het epitheel van caecum en colon, en op de vorming van lipopolysacchariden of andere endotoxinen in de dikke darm.

- De invloed van excessieve fermentatie in de dikke darm op de integriteit/permeabiliteit van het epitheel, de verschijning van endotoxinen (o.a. lipopolysacchariden) in systemisch bloed en de metabole respons die dit teweeg brengt.

- De invloed van excessieve fermentatie in de dikke darm op de elektrolytenbalans, de waterhuishouding van de melkkoe, de gehalten aan kationen in bloed, en het bloed zuur-base evenwicht, bij zowel kationrijke als -kationarme rantsoenen voor melkvee tijdens de close-up periode en de vroege lactatie. 
- Vaststelling van de grenzen aan het aanpassingsvermogen van epitheel in de dikke darm (door metingen in de dikke darm, systemisch bloed en verse feces).

- Invloed van een systemische infectie / immuun challenge en/of een metabole verzuring op de verzuring van de dikke darminhoud en op het functioneren van het epitheel. 


\section{$5 \quad$ Metabole acidose}

Er zijn verschillende oorzaken aan te wijzen voor het ontstaan van een metabole acidose (een verzuring van het zuur-base evenwicht in bloedplasma) zoals een ophoping van zuren, een negatieve of relatief lage kation-anionbalans, of een ophoping van kooldioxide in bloed. Zuren in het bloed kunnen uit diverse bronnen afkomstig zijn. Zuren kunnen afkomstig zijn van de microbiële fermentatieprocessen in de pens en dikke darm (en eventueel de dunne darm). Zuren die in het bloed worden opgenomen betreffen hoofdzakelijk azijnzuur, propionzuur, boterzuur en onder bepaalde omstandigheden ook melkzuur. Boterzuur wordt tijdens het transport naar bloed in het epitheel grotendeels omgezet in het ketonzuur $\beta$ hydroxy-boterzuur, ook wel met de term ketonlichaam aangeduid. Zuren kunnen echter ook een endogene oorsprong hebben en afgegeven worden aan bloed. Bij de mobilisatie van lichaamsvet worden langketen vetzuren afgebroken en omgevormd tot $\beta$-hydroxy-boterzuur en aceto-azijnzuur (en soms aceton) in de lever. Glucose kan onder bepaalde omstandigheden omgezet worden in melkzuur. Voor humaan worden in de literatuur als bron van melkzuur genoemd intensieve spieractiviteit, ernstige ontstekingen, verwondingen, een slecht functionerende lever en verlies van lichaamsvocht. Voor melkvee richt de literatuur zich hoofdzakelijk op melkzuurvorming in de pens, hoewel melkzuurvorming waarschijnlijk ook rondom afkalven en bij andere extreme spieractiviteit voorkomt. Het $\beta$-hydroxyboterzuur en aceto-azijnzuur hebben een pKa waarde van resp. 4.7 en 3.6. Deze waarden komen redelijk overeen met de pKa waarden voor resp. vluchtige vetzuren (azijnzuur, propionzuur, boterzuur; 4.8-4.9) en melkzuur (3.9). Een verhoogd kooldioxidegehalte van bloed kan veroorzaakt worden door een verminderde respiratoire capaciteit van de koe. De intensiteit en frequentie van ademhaling hebben daarmee een directe invloed op het kooldioxide gehalte in bloed. Overige factoren die een verlaging van de $\mathrm{pH}$ waarde van bloedplasma teweeg kunnen brengen, lijken een geringere rol te spelen (uitgezonderd extreme situaties zoals bijv. een sterke wijziging in de kation-anionbalans, of in de bijdrage het bufferend vermogen van eiwitten).

Genoemde factoren die een verzuring kunnen geven van bloed zijn meteen ook de aangrijpingspunten van regulatiemechanismen om de $\mathrm{pH}$ van bloedplasma te bufferen. Een versneld metabolisme van zwakke zuren die in het bloed worden opgenomen, een verlaagde kooldioxideconcentratie door een intensievere of verbeterde ademhaling, en een verhoogd concentratieverschil tussen kationen en anionen gereguleerd door de nierfunctie gaan een verzurend effect tegen. Hoewel ook bloedeiwitten een bufferende werking kunnen hebben, lijkt dit doorgaans een geringere rol te spelen, en bovendien worden zulke eiwitten slechts op de wat langere termijn effectief en zijn alleen werkzaam op het algehele niveau (de volledige bloedcirculatie), niet voor regulatie van schommelingen van de $\mathrm{pH}$ binnen een dag. Een belangrijk mechanisme dat ten grondslag ligt aan de buffering van de $\mathrm{pH}$ van bloedplasma (evenals in andere compartimenten van het lichaam), is ion-transport en de regulering van de ion of elektrolyten uitscheiding door de nieren. Feitelijk betreft dit het middels resorptie terugbrengen van ionen uit de pro-urine in de nieren, die in eerste instantie als filtraat uit de haarvaten is geperst. Dit reguleringsproces is zeer actief zoals ook blijkt uit het hoge aandeel van de nieren in de energetische onderhoudsbehoefte van de koe, die in geval van de nieren bovendien voor maar liefst $70 \%$ toe te schrijven is aan iontransportmechanismen (Tabel 1). Regulatie van bloed $\mathrm{pH}$ betreft dus vooral de regulatie van de gehaltes van (sterke) ionen door de nieren en van de gehaltes in bloedplasma, een voldoende metabole verwerkingscapaciteit van de zwakke zuren in verschillende organen (m.n. de lever), regulatie van de kooldioxide concentratie in bloed via de ademhaling en een voldoende snelle uitwisseling met de buitenlucht in de luchtwegen, en op de wat langere termijn een aanpassing van het metabolisme van de eiwitten in bloedplasma (mogelijk in extreme en langdurige gevallen van metabole acidose).

De pH van bloed wordt nauw gereguleerd en ligt normaal tussen 7.35 en 7.45 in arterieel bloed. Vanwege de cruciale rol van de $\mathrm{pH}$ van bloedplasma voor uiteenlopende fysiologische functies, reageren de regulatiemechanismen in het lichaam zeer sterk en snel om veranderingen in $\mathrm{pH}$ tegen te gaan. De $\mathrm{pH}$ waarde is een van de meest gereguleerde fysiologische parameters in bloed en weefsels van organen (m.n. intracellulair). Een metabole acidose gaat doorgaans dan ook gepaard met een slechts zeer geringe daling van de $\mathrm{pH}$ van bloedplasma. De mechanismen die zorg dragen voor de regulatie, en de relatief hoge metabole activiteit van de betrokken organen brengen echter hoogstwaarschijnlijk hoge 
energetische kosten met zich mee, zoals reeds bediscussieerd in hoofdstuk 3 (Tabel 1). Ondanks de hoge mate van regulering van de zuurgraad van bloedplasma en een slechts zeer geringe daling van de $\mathrm{pH}$ van bloedplasma (met een orde van grootte van 0.1 - 0.2 eenheden; Bigner et al., 1996; Oetzel et al., 1991), worden uiteenlopende metabole neveneffecten hieraan gerelateerd die een negatieve invloed hebben op het functioneren en de gezondheid van de melkkoe. Deze zijn in Figuur 5 schematisch weergegeven en gebaseerd op een literatuurstudie van Enemark et al. (2002). In deze studie wordt niet zozeer ingegaan op de mechanismen die op weefselniveau spelen, of op de factoren die een invloed hebben op deze mechanismen, of op de wijze waarop de uiteenlopende factoren zich tot op elkaar verhouden en samenhangen met de voeding. Daarentegen wordt het geheel van interacties als één groot complex veterinair probleem gepresenteerd en op hoofdlijnen beschreven. Er zijn in de literatuur meer concrete aanwijzingen te vinden waarmee het ontstaan van een metabole acidose en de gevolgen daarvan te onderbouwen zijn. Er is nauwelijks literatuur waarin metabole acidose zelf het onderwerp van onderzoek is geweest (m.a.w. geen formulering van hypotheses rondom metabole acidose). De meeste literatuur richt zich op het Ca-metabolisme in transitiekoeien en de positieve uitwerking van het voeren van een rantsoen met verlaagd kation-anion verschil op het eind van de droogstand en de mate waarin dit een metabole acidose opwekt (Fredeen et al., 1988). Ook is reeds decennia lang de incidentie en het en de achtergrond voor het ontstaan van ketose bij melkvee bij melkvee bekend, en de gevolgen daarvan voor de prestaties van melkvee (Drackley, 1999). Echter, opnieuw, er zijn weinig studies waarin de mechanismen achter het ontstaan en de gevolgen van de metabole acidose onderwerp van studie waren. In de volgende secties wordt gepoogd de problematiek van een metabole acidose voor een melkkoe diepgaander te analyseren, met inbegrip van de onderliggende mechanismen en invloedfactoren, en om met voorstellen voor verder onderzoek te komen.

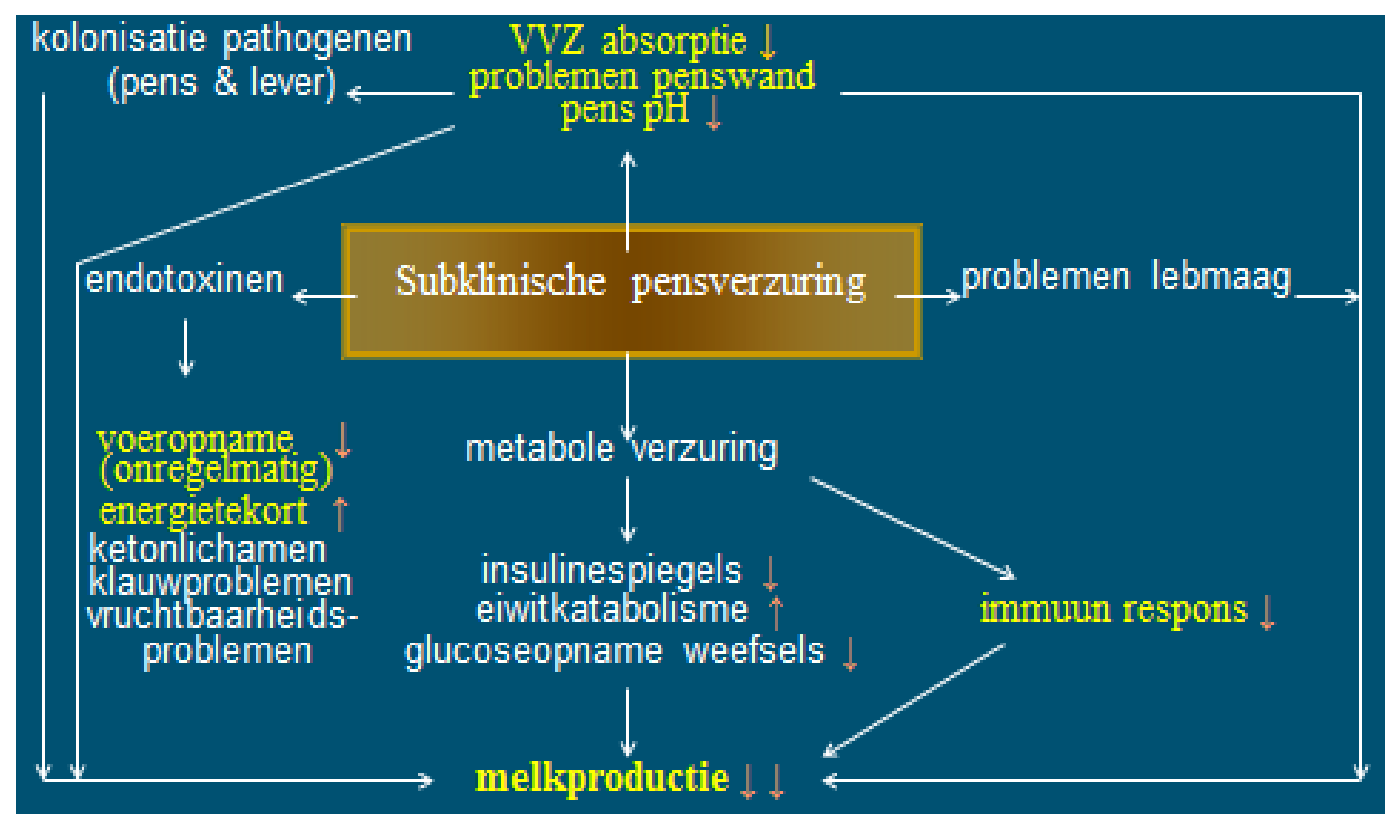

Figuur 5 Schema voor het negatieve effecten van een subklinische pensacidose, en als gevolg daarvan metabole acidose, op de lactatiestart van melkvee (herleid uit Enemark et al., 2002).

\subsection{Ketose (tijdens de negatieve energiebalans na afkalven)}

Ketose, ook wel slepende melkziekte genoemd, is de omschrijving voor de fysiologische toestand waarin een melkkoe terecht kan komen bij een sterk negatieve energiebalans en een hoge vraag naar glucose tijdens de vroege lactatie met een snel stijgende melkproductie, of ook bij koeien op een rantsoen dat weinig glucogene nutriënten levert (maar deze oorzaak is van minder belang in Nederland). De doorgaans snel stijgende voeropname na afkalven levert minder metaboliseerbare energie dan de melkkoe nodig heeft voor de nog sneller stijgende melkproductie, en het restant van de benodigde metaboliseerbare energie voor melkproductie is afkomstig uit gemobiliseerde lichaamsreserves. In deze toestand 
mobiliseert de melkkoe lichaamsvet wat vrijkomt in het bloed in de vorm van niet-geësterificeerde vetzuren (NEFA's) die door de lever omgezet worden in acetoacetaat, $\beta$-hydroxyboterzuur (en soms aceton). Indien deze producten niet snel genoeg opgenomen en gemetaboliseerd worden door andere organen (o.a. de uier) dan hopen zij zich op in het bloed en kunnen een metabole acidose veroorzaken omdat deze producten zuren zijn met een pKa die vergelijkbaar is aan die van vluchtige vetzuren en melkzuur. Voordat een acidose optreedt is er in eerste instantie sterke regulatie door de melkkoe om dit te voorkomen. Deze regulatiemechanismen kunnen echter tekort schieten met als gevolg een sterk ketotische toestand (sterkere metabole acidose) en ziekteverschijnselen bij de melkkoe. Dit is een ernstige situatie met een grote impact op het gedrag en welbevinden van de koe en met een sterk negatief effect op de voeropname. Een te langzame stijging van de voeropname na afkalven vergroot mogelijk het gat tussen benodigde en opgenomen energie, en leidt mogelijk tot juist meer mobilisatie van lichaamsvet wat het probleem van ophoping van ketonzuren en de mate van een metabole acidose alleen maar verergert (Roche et al., 2013). Niet uitsluitend een overmatige mobilisatie van lichaamsvet en een te lage verwerkingscapaciteit van de lever is oorzaak van het ontstaan van een ketose. Ook andere gezondheidsproblemen zoals infecties kunnen het ontstaan van de ketose induceren. Indien de koe in een sterk katabole toestand wordt gebracht dan kan dit een vergelijkbaar effect hebben en een metabole acidose veroorzaken.

Het aanbod aan glucogene nutriënten kan een beperkende factor zijn voor de verwerkingscapaciteit van de lever voor gemobiliseerde vetzuren. Een optimaal aanbod aan glucogene nutriënten vermindert dus het risico op het ontstaan van ketose tijdens de vroege lactatie tijdens een sterk negatieve energiebalans, en voorkomt mogelijk een compensatie door de koe met eiwitkatabolisme om glucose te vormen, eveneens in de lever (gluconeogenese). Een extra behoefte voor aanmaak van glucose zou niet bevorderlijk zijn voor de gezondheid van de koe omdat direct na afkalven de koe zich niet alleen in een negatieve energiebalans maar tevens in een negatieve eiwitbalans bevindt (Van Knegsel et al. 2007). Gedurende de gehele duur van de negatieve energiebalans nemen de viscerale organen sterk in omvang en activiteit toe met de toename van de voeropname. Bovendien neemt de drain van eiwit en glucose richting melkproductie in het uier snel toe in dezelfde periode (met relatief hoge eiwitgehaltes bij de lactatiestart). Ook is er een extra eiwit- en glucosebehoefte ten behoeve van de immuunrespons op uiteenlopende infecties en voor het benodigde herstel van weefsels als gevolg van het afkalven.

Succesvolle behandelingen van ketose zijn een toediening van glucose of propyleenglycol wat middels een stijging van het glucosegehalte in bloed het insulineniveau verhoogt en de mobilisatie van lichaamsvet remt (Gordon et al., 2013). Hierdoor verdwijnen de metabole acidose-verschijnselen, de ophoping van ketonlichamen in bloed en de negatieve uitwerking op het gedrag en de voeropname door de koe. Er bestaat een grote individuele variatie tussen koeien in het gehalte ketonlichamen in bloed waarbij ketotische verschijnselen beginnen op te treden. De achtergrond en betekenis van die variatie is nog steeds onduidelijk. Het is echter wel waarschijnlijk dat de ophoping van zuren in bloed bijdraagt aan een metabole verzuring. Door het wegnemen van de ketose-verschijnselen stijgt de voeropname van de melkkoe weer wat het dier opnieuw in staat stelt om zelfstandig het energetische gat tussen energiebehoefte voor melkproductie en energieopname met voer te dichten. Samengaand hiermee vlakt de snelheid waarmee lichaamsvet wordt gemobiliseerd af wat de aanleiding voor de ketose wegneemt. Naast een verbeterd aanbod van glucose en glucose-precursors is het ook mogelijk om de buffering en transport van NEFA's in de lever te stimuleren. Zo is een stimulerende invloed aangetoond van pensbeschermd choline op de concentratie van carnitine in de lever (met directe beïnvloeding van metabole processen in de mitochondria), de excretie van lipoproteinen als afvoerroute van langketenvetzuren afkomstig uit gemobiliseerd lichaamsvet, en het koolhydraat metabolisme in de levercellen (Zom et al., 2011; Goselink et al., 2013).

Ten slotte, evenals een achterblijvende toename van de voeropname na afkalven, kan ook een slechte vertering van het rantsoen (ten gevolge van rantsoensamenstelling, voerstrategie, of een pens- en/of dikke darm acidose) bijdragen aan een lager nutriëntenaanbod aan het metabolisme van de melkkoe. Indien de koe dit lagere nutriëntenaanbod compenseert met een verhoogde mobilisatie van lichaamsvet dan kan dit een extra aanleiding of risico vormen voor de ophoping van ketonlichamen in bloed en het ontstaan of verergeren van een ketotische toestand. 


\subsection{De rol van insuline en insulineresistentie bij melkvee}

Insuline heeft een bepalende rol bij het ontstaan van ketose, of heeft in het algemeen een grote rol tijdens de toestand van een metabole acidose. In Figuur 6 zijn de verschillende aangrijpingspunten van insuline schematisch weergegeven. Fysiologisch verschilt de melkkoe tijdens de vroege lactatie met een sterk negatieve energiebalans sterk van éénmagigen wat betreft de rol die insuline. Het primaire defect bij een metabole acidose / ketose bij éénmagigen komt goed naar voren in geval van suikerziekte bij de mens (diabetes mellitus) die eveneens in een katabole toestand verkeren. Deze situatie wordt gekenmerkt door een hoog concentratie van glucose, langketen vetzuren (NEFA's) en ketonen in bloed, een lage $\mathrm{pH}$ waarde en insuline-concentratie, en een verhoogde insuline-resistentie. Het primaire defect is in dit geval de insulinewerking omdat er te weinig insuline is, of de insuline niet werkzaam is. Hierdoor treedt er een overmatige gluconeogenese op in de lever en wordt de lipolyse in vetcellen niet geremd. De hoge bloedconcentraties van glucose en ketonen en de metabole acidose leiden tot insulineresistentie, die de situatie verergert en de factoren die de acidose veroorzaakten alleen maar versterken. Hiermee is een vicieuze cirkel gecreëerd die alleen te doorbreken is met een langdurige milde verhoging van de insulinespiegels in bloed. Een milde verhoging van insuline zal de lipolyse in vetcellen remmen waardoor de toevloed van vetzuren in bloed afneemt en de lever weer voldoende capaciteit krijgt om NEFA's te oxideren en minder ketonlichamen aan het bloed afgeeft en eruit verwijderd. De $\mathrm{pH}$ in bloed wordt weer neutraal en de acidose en insulineresistentie nemen af, evenals het glucosegehalte in bloed die te hoog was vanwege het ontbreken van de stimulerende invloed van insuline op de glucoseopname door spieren vetweefsel, en het ontbreken van de remmende werking van insuline op de gluconeogenese in de lever (Figuur 6). De oplossing bij diabetes mellitus ligt dus in de verhoging van de insulinespiegels en het tegengaan van de insulineresistentie. Dit kan (deels) ook bewerkstelligd worden via de voeding, door weinig suikers, weinig verzadigde vetten, langzaam verteerbare koolhydraten en meer vezels te consumeren, en meer lichaamsbeweging te hebben.

\section{Actions of Insulin}

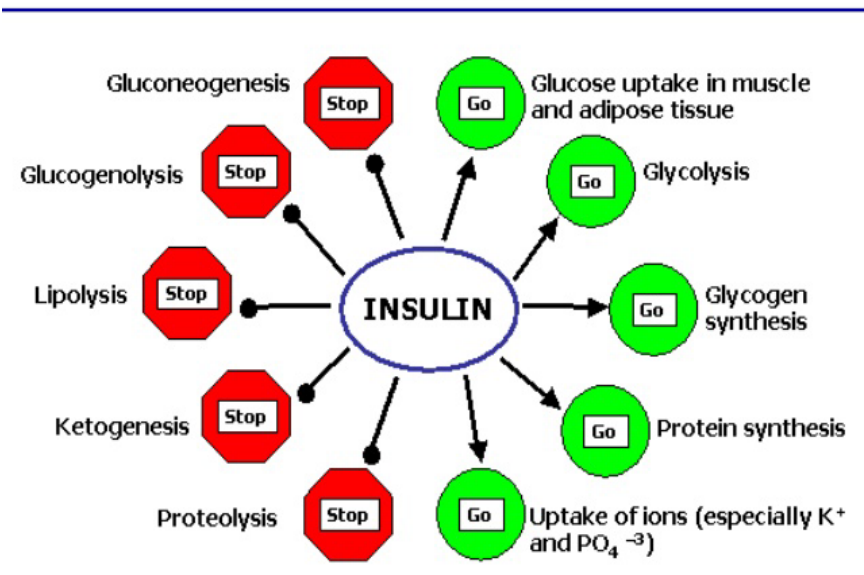

Figuur 6 Schematisch overzicht van de verschillende acties van insuline bij uiteenlopende fysiologische processen of functies. (bron: http://www.medbio.info/horn/time\%2034/homeostasis_2.htm).

De situatie bij melkvee is anders omdat er van nature al sprake is van insulineresistentie en lage bloedconcentraties van insuline tijdens de lactatiestart, waarin sprake is van een negatieve energiebalans en intensieve lipolyse. Bij melkvee is er dus een relatief laag in plaats van een hoog glucosegehalte tijdens de vroege lactatie vanwege de grote drain van glucose naar het uier ten behoeve van melkproductie, naast een hoge concentratie aan NEFA's, en een hoge concentratie van ketonlichamen en een lage $\mathrm{pH}$ van bloed in geval van een ketose. De primaire oorzaak voor het ontstaan van een ketose / metabole acidose bij melkvee is dat de lever de grote toevoer van vetzuren en NEFA's niet meer kan verwerken evenals de organen die deze nutriënten oxideren (bijv. spierweefsel) of voor synthesedoeleinden gebruiken (het uier), en ketonlichamen begint af te geven die zich ophopen in bloed. Dit geeft een metabole acidose die de van nature reeds aanwezige insulineresistentie verergert, waarmee insuline nog minder effectief wordt. Het defect in (de afname van) de insulinewerking is hierbij dus secundair, i.t.t. de situatie bij diabetes mellitus bij de mens waarbij de metabole acidose het gevolg is van een verminderde 
insulinewerking als defect. Het defect bij de melkkoe is de overschreden verwerkingscapaciteit van de lever, het eventuele gebrek aan glucose terwijl dat juist nodig is om de verwerkingscapaciteit van de lever op peil te houden, of een overmatige mobilisatie van lichaamsvet (een te sterke negatieve energiebalans, een achterblijvende voeropname). De glucosebehoefte van de lever gaat samen met een relatief lage beschikbaarheid van glucose in bloed vanwege het snel toenemende glucoseverbruik voor melkproductie, of vanwege een rantsoen dat tot een te laag aanbod aan glucogene prescursors oplevert, of vanwege een situatie met een verhoogd glucoseverbruik zoals met een geactiveerd immuunsysteem (bijv. met infecties) of met herstel van weefsels (na afkalven) of met groei van weefsels (groei van het maagdarmpakket).

$\mathrm{Er}$ is in de melkkoe tijdens de vroege lactatie eerder een tekort dan van een overschot aan glucose. De conditie van insulineresistentie maakt dat de glucose die beschikbaar is niet gebruikt wordt door spieren vetweefsel (deze zijn insulinegevoelig) maar beschikbaar blijft voor melksynthese; de hersenen en het uier zijn insuline-ongevoelig. Om het ontstaan van een ketose / metabole acidose of een gebrek aan glucose bij de koe te voorkomen moet het aanbod aan glucogene nutriënten verhoogd worden. Dit verhoogt de insulineconcentraties en remt de overmatige lipolyse als primaire oorzaak van een sterke ophoping van ketonlichamen in bloed. Het remt ook de gluconeogenese, maar door een vermindering van de insulineresistentie kan het ook weer het gebruik van glucose mogelijk maken in andere weefsels dan het uier (spierweefsel) (Figuur 6). Het voorkomen van een gelijktijdige acidose in de pens door te sturen op een verminderde productie van vetzuren vanuit de pens en het maagdarmkanaal lijkt in deze situatie geen optie omdat dit het energieaanbod verlaagt en de lipolyse eerder versterkt dan afzwakt. Juist een toename van nutriënten uit de voervertering is gewenst en een hoge voeropname. Zo hebben maatregelen die de ketose / metabole acidose verminderen een gunstige uitwerking op de voeropname, en vice versa. De metabole acidose is ook te verminderen met bufferende Na- of K-zouten die de acidose als symptoom wegnemen. Indien dit gebeurt met Na-propionaat dan is een extra bijkomstigheid dat tevens extra glucogene nutriënten aangeleverd worden (wat eveneens een behandeling is van ketose).

\subsection{Overige oorzaken metabole acidose}

Bijkomstige factoren kunnen de mate van ketose / metabole acidose mogelijk verergeren. Mogelijk ontstaat een metabole acidose eerder bij relatief kationarme rantsoenen waarbij zich minder kationen in bloed bevinden die een bufferende uitwerking hebben op de bloed $\mathrm{pH}$. Indien de speekselproductie op dergelijke rantsoenen als drain voor de kationen in bloed in stand blijft (de speekselsecretie is een actief en gereguleerd proces wat veel energie vergt omdat de kationen tegen een concentratie gradiënt in worden uitgescheiden) dan is de uitwerking op de kationstatus van bloed mogelijk negatief. Met een lagere kationstatus is er mogelijk eerder aanleiding voor het ontstaan van een metabole acidose.

Daarnaast is er de mogelijkheid van een tijdelijke immuunrespons (al dan niet veroorzaakt door gebeurtenissen in de pens of dikke darm) die bijdraagt aan het ontstaan of intenser maken van een metabole acidose. Een sterke immuunrespons maakt dat de melkkoe in een nog meer katabole toestand terecht komt. Lipopolysacchariden vanuit de pens en/of dikke darm geven dan wel geen infectie maar ze geven wel een sterke immuunrespons met productie van acute fase-eiwitten om de lichaamsvreemde stof te neutraliseren. Wellicht geeft het ook een afname van de voeropname vanwege de ziekteverschijnselen die optreden, met als gevolg dat de conditie van insulineresistentie en sterke mobilisatie van lichaamsvet eerder intensiveert dan vermindert. Bovendien wordt een sterke negatieve energiebalans en een overmatige mobilisatie van lichaamsvet dikwijls geassocieerd met een verminderde functie van immuuncellen (Figuur 7), wat maakt dat een infectie onvoldoende wordt afgeweerd en in intensiteit blijft toenemen of chronisch wordt na het moment van infectie.

Een verminderde respiratoire capaciteit van de longen of een verminderde ademhaling vanwege de ziekteverschijnselen is waarschijnlijk niet de primaire oorzaak van een ketose, maar eerder een gevolg die de verschijnselen verergerd. Een verminderde respiratoire capaciteit werkt de gasuitwisseling in de longen tegen en kan tot een ophoping van kooldioxide in bloed leiden, met een extra verzurend effect op bloed.

Ook gezondheidsproblemen in het uier (mastitis, een laag melkvetgehalte) laten mogelijk de belangrijkste drain wegvallen van de grote hoeveelheid vetzuren en ketonzuren die dagelijks aan het bloed wordt afgegeven. De insulineresistentie blijft echter aanwezig en de sterk hormonaal gedreven mobilisatie van lichaamsvet gaat door ondanks een de verminderde drain naar melkvetsynthese, wat mogelijk eerder tot een ophoping van ketonzuren in bloed leidt en ketose veroorzaakt. 
Ten slotte, kunnen ook watergebrek, hittestress en ernstige verliezen van kationen een lage kationstatus in bloed veroorzaken wat een metabole verzurend effect heeft en de verschijnselen van ketose versterkt.

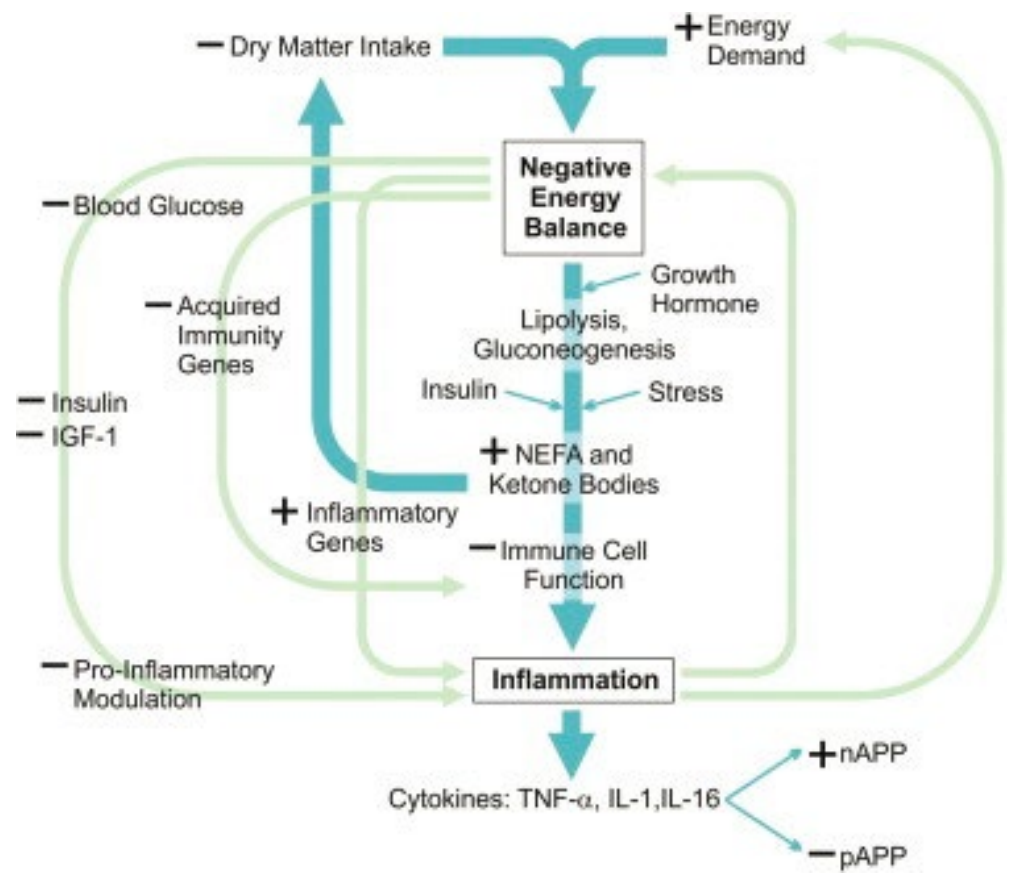

Figuur 7 Schema ontleend aan Esposito et al. (niet gepubliceerd) waarin de causale verbanden zijn weergegeven tussen een negatieve energiebalans en een immuunrespons (infectie) tijdens de vroege lactatie. De symbolen + en - geven resp. een toename en afname aan in concentraties; NEFA, niet-geesterificeerde langketen vetzurens; IGF-1, insulin-like growth factor 1; TNF- $\alpha$, tumor necrosis factor $a$; IL-1 en IL-6, interleukine 1 en 6; nAPP en pAPP, negatieve en positieve acute fase-eiwitten.

(acute fase-eiwitten zijn eiwitten waarvan de concentratie in het bloed al in een vroeg stadium van een infectie stijgt (positieve acute fase-eiwitten) of daalt (negatieve acute fase-eiwitten).

\subsection{Relatie metabole acidose en pens/dikke darm acidose}

Er zijn relaties denkbaar tussen een acidose in de pens of de dikke darm, en een metabole acidose. De grote hoeveelheid zuur die geproduceerd wordt in het maagdarmkanaal en daar een acidose veroorzaakt, wordt voor een groot deel geabsorbeerd in bloed. De verwerkingscapaciteit van deze zuren is doorgaans hoog zodat er geen ophoping van deze zuren plaats vindt in het bloed.

Indien er sprake is van een (risico op) ketose / metabole acidose dan zijn er interacties met een acidose in de pens en de dikke darm denkbaar. Tijdens een ketose kan de absorptie van het grotendeels in de pens gevormde boterzuur dat in de penswand omgezet wordt in $\beta$-hydroxyboterzuur een extra bijdrage leveren aan de reeds opgehoopte ketonlichamen in bloed. Ook van een verminderde drain van het uit het maagdarmkanaal geabsorbeerde azijnzuur en boterzuur/ $\beta$-hydroxyboterzuur in het uier voor de synthese van melkvet zou kunnen bijdragen aan de ophoping van deze zuren in bloed.

Een infectie van de penswand of de wand van de dikke darm, of het doorlaten van endotoxinen van microbiële oorsprong, kunnen de melkkoe in een nog meer katabole toestand brengen vanwege de veroorzaakte immuunrespons. Dit verhoogt vervolgens de insulineresistentie en houdt de mobilisatie van lichaamsvet in stand houdt of verhoogt deze zelfs, wat op haar beurt weer kan bijdragen aan het overschrijden van de verwerkingscapaciteit van de lever en de afgifte van ketonlichamen aan bloed kan verhogen.

Een acidose in de pens zou kunnen leiden tot extra afgifte van kationen aan de pens om de pensinhoud te bufferen, met als gevolg depletie van kationen in bloed. Doorgaans zullen de nieren een sterk regulerende werking hebben op de kation-balans in bloed en zullen er geen tekorten optreden. In extreme gevallen zoals watergebrek, hittestress, een zeer kation-arm rantsoen (vnl. maiskuil in plaats van graskuil), of grote verliezen van kationen met de feces vanwege excessieve fermentatie in de dikke darm, kunnen mogelijk toch tekorten optreden wat bijdraagt aan het risico en de ernst van een ketose / metabole acidose. 
Omgekeerd is het ook denkbaar dat omstandigheden die aanleiding geven tot een metabole acidose kunnen bijdragen aan het ontstaan van een acidose in de pens of de dikke darm. Infecties en een sterke immuunrespons leiden mogelijk tot een andere metabole prioritering van het energie- en eiwitverbruik. Indien dit ten koste gaat van de benodigde energie en eiwit voor de groei en ontwikkeling van de pensen darmwand tijdens de lactatiestart, dan zal er een beperking zijn in de ontwikkeling van de absorptiecapaciteit tijdens de vroege lactatie. Deze ontwikkeling is nodig om de absorptiecapaciteit gelijke tred te laten houden met de toenemende hoeveelheden zuur die geproduceerd worden met een stijgende voeropname. Indien de stijging van de voeropname stand houdt, wat nodig is voor de melkkoe om het energietekort tijdens de negatieve energiebalans op te heffen, dan zou er een ophoping van zuur kunnen optreden in de pens en de dikke darm.

Ook is het denkbaar dat bij een ketose en een verhoogde concentratie van $\beta$-hydroxyboterzuur in bloed, het transport van het in de pens- en darmwand gevormde $\beta$-hydroxyboterzuur (uit boterzuur) geremd is vanwege een afgenomen concentratiegradiënt. Ook voor azijnzuur bestaat er een lagere concentratiegradiënt tussen de pens en bloed dan voor propionzuur en boterzuur, die er aan bijdraagt dat de fractionele absorptiesnelheid van azijnzuur uit de pens navenant lager is dan voor propionzuur en boterzuur (Dijkstra et al., 1993).

Ten slotte, indien een lage kationstatus in bloed ook aanleiding is voor een verlaagde kationsecretie met speeksel, dan zal dit speeksel een geringere bufferende werking kunnen uitoefenen in de pens. Er is echter geen onderzoek bekend op dit terrein.

Tabel 2 geeft nog eens een opsomming van de fysiologische kenmerken van de melkkoe, de metabole fenomenen die samengaan met de incidentie van acidose, de directe oorzakelijke factoren voor het optreden van een acidose, en de processen die samenhangen met het ontstaan van een acidose. 
Tabel 2. Overzicht van de kenmerken van de fysiologisch status van een melkkoe tijdens de vroege lactatie, de metabole fenomenen die mogelijk samengaan met het optreden van acidose, de directe oorzakelijke factoren van acidoses in de pens, de dikke darm of metabool, en de processen die aanleiding zijn tot het ontstaan van deze acidoses.

Fysiologische status

Metabole fenomenen

Oorzakelijke factoren voor acidose

\section{Proces dat leidt tot acidose}

Hoge zuurproductie Trage absorptie Trage menging inhoud Lage vloeistofpassage Lage doorbloeding LPS ?

Hoge voeropname Veel, snelle FOS

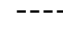

Sterke stijging voeropname

maagdarmkanaal
Pens

Ophoping zuren

(Lage kationconc.)

Beschadigde penswand

-

Negatieve energiebalans \& mobilisatie lichaamsvet

Groei maagdarmpakket \& lever

Stijging capaciteit melksynthese

Sterke stijging van de capaciteit voor zuurabsorptie uit

Verhoogde aanspraak op immuunsysteem

Anionrijke voeding tijdens droogstand (ivm Ca-status vroege lactatie)

Aanspraak lever \& glucosetekort \& vorming ketonlichamen door lever

Vorming melkzuur door metabolisme ( $\mathrm{mn}$ rondom afkalven)

Insulineresistentie \& lage insulinespiegel

\section{Darm}

Ophoping zuren

(Lage kationconc.)

Beschadigde darmwand

Besch

Hoge zuurproductie

Trage absorptie

Slechte pensvertering

Lage vloeistofpassage

Lage doorbloeding

LPS ?

Hoge voeropname

Veel bestendige OS

----

\section{Metabool}

Ophoping zuren

Lage kationconc.

Slechte leverfunctie

Extreme belasting

Hoge zuurafgifte

Trage verwerking

Wegvallen drain uier

Watergebrek/Hittestress

----

Immuunrespons

Lage voeropname

Respiratoire beperkingen

Slechte doorbloeding periferie) 


\subsection{Conclusies \& onderzoekfactoren}

Concluderend, de behandeling van een ketose / metabole acidose bij melkvee moet gericht zijn op het verhogen van het glucoseaanbod en de insulinespiegels om de mobilisatie van lichaamsvet (lipolyse) te verminderen. Ook moet de noodzaak voor mobilisatie van lichaamsvet verminderd worden door de negatieve bijverschijnselen van een ketose / metabole acidose te neutraliseren, zoals een onregelmatige en achterblijvende (stijging van) de voeropname tijdens de lactatiestart. Aanvullende oorzaken als een systemische immuunrespons, een verminderd functioneren van het uier, en een suboptimale ademhaling werken het ontstaan van een ketose / metabole acidose in de hand. Deze verhogen de insulineresistentie, geven een verdere verlaging van de insulinespiegels en brengen de melkkoe in een nog sterkere katabole toestand.

Hoewel de oorzaken van een metabole acidose bij diabetes mellitus in mensen niet vergelijkbaar zijn met de oorzaken in melkvee, is de ernst van een metabole acidose voor de gezondheid bij de mens (levensbedreigend) wel kenmerkend voor de problematische situatie waarin een melkkoe met een metabole acidose zich bevindt tijdens de vroege lactatie. Het lijkt raadzaam om iedere bijdrage van een acidose in de pens of de dikke darm aan het ontstaan van een metabole acidose te voorkomen. Tijdens de lactatiestart wordt het aanpassingsvermogen van het pens- en dikke darmepitheel en van de lever, evenals het immuunsysteem van de melkkoe, het sterkst aangesproken. Voor een groot deel is dit hormonaal bepaald (mobilisatie lichaamsvet, insulineresistentie) en waarschijnlijk ook afhankelijk van het genotype, wat verklaart waarom incidentie van metabole acidose / ketose zo variabel is en de gevoeligheid van individuele dieren kan verschillen. Er zijn aangrijpingspunten om via management de metabole omstandigheden die het ontstaan van een metabole acidose in de hand kunnen werken, te voorkomen of te compenseren. Hierbij moet gedacht worden aan het voeren van een glucogene type rantsoen, het voorkomen van extra absorptie van ketonlichamen vanuit de pens (het voorkomen hoge bijdrage van boterzuur), hygiëne, het voorkomen van chronische infecties of een verminderde immuunstatus van de koe, en het stimuleren van de voeropname en/of de energieopname. 


\section{6 \\ Interacties tussen de gevolgen van pens-acidose, darm-acidose en metabole acidose}

Uit voorgaande hoofdstukken blijkt een mogelijke relatie tussen acidose in het maagdarmkanaal en het optreden van een metabole acidose tijdens de vroege lactatie, indien de acidose in het maagdarmkanaal ook metabole consequenties heeft voor de melkkoe. Dit kan een veranderde integriteit en permeabiliteit van het epitheel zijn met mogelijk negatieve gevolgen voor eiwitsyntheseprocessen in pens- en darmepitheel, met binnentreding van lichaamsvreemde stoffen in het bloed wat een immuunrespons opwekt in de maagdarmwand of systemisch, met een weerslag op de zuur-base evenwichten in bloed en versterking van een metabole acidose, en met het in een katabole toestand brengen van de melkkoe op de reeds verminderde functionaliteit van immuuncellen tijdens de negatieve energiebalans.

Risico-factoren voor het ontstaan van een metabole acidose zoals een sterk negatieve energiebalans en mobilisatie van lichaamsvet, ontstekingen vanwege een verminderde weerstand, de geboorte van het kalf, de snelle toename van de melksynthese in het uier, een onderdrukking of ontregeling van de immuunrespons, en een onvoldoende stijgende voeropname met onvoldoende glucogene nutriënten zijn alle sterk gerelateerd wat betreft oorzaak en gevolg. Dit bemoeilijkt interventie op ieder van deze factoren om het ontstaan van een metabole acidose te voorkomen. Er zijn verschillende vicieuze cirkels denkbaar die maken dat een melkkoe na het afkalven in een negatieve spiraal kan komen van toenemende problemen met als uiteindelijke uitkomst een ernstige metabole acidose of ketose. Hieronder worden enkele van deze interacties en vicieuze cirkels nog eens opgesomd:

- $\quad$ vicieuze cirkel "mobilisatie vetweefsel - ketose - katabole status/mobilisatie "

Door de sterke mobilisatie van lichaamsvet tijdens de lactatiestart hopen ketonzuren zich op in bloed en ontstaat een metabole acidose die de insulineresistentie verder verhoogt, insuline verlaagt, en de mobilisatie van lichaamsvet stimuleert.

- $\quad$ vicieuze cirkel "negatieve energiebalans - immuunrespons - negatieve energiebalans"

Een infectie tijdens de lactatiestart brengt een immuunrespons op gang en brengt de koe in een meer katabole toestand, die de insulineresistentie verhoogt en insulinespiegels verlaagt. Lichaamsvet en -eiwit wordt gemobiliseerd wat een metabole acidose bevordert, die op haar beurt de functionaliteit van immuuncellen vermindert, de infectie onvoldoende tegengaat, en een nog grotere immuunrespons nodig maakt.

- $\quad$ vicieuze cirkel "lage voeropname - pensacidose met hogere krachtvoergift - metabole acidose" Een te lage (of onregelmatige) voeropname door de koe na afkalven door de ziekteverschijnselen ontstaan door een metabole acidose, is te compenseren door mee energie met krachtvoer te verstrekken. Indien dit de metabole acidose versterkt of vanwege een te permeabel epitheelweefsel een immuunrespons opwekt (via lipopolysacchariden) dan werkt het extra krachtvoer averechts en wordt de mate van negatieve energiebalans mogelijk vergroot en de metabole acidose versterkt.

- vicieuze cirkel "metabole acidose - hogere vetmobilisatie - hogere melkproductie - hogere voeropname - sterkere metabole acidose"

Indien een koe een metabole acidose heeft vanwege een hoge mate van mobilisatie van lichaamsvet en ophoping van ketonzuren in bloed, dan komt het dier in een nog meer katabole toestand terecht door een verlaging van insuline en verhoging van de insulineresistent, en wordt meer lichaamsvet en -eiwit gemobiliseerd. Indien de koe hierop reageert door de melkproductie te verhogen (waarop koeien geselecteerd zijn) dan stimuleert dit wellicht de voeropname wat een metabole acidose verder voedt, totdat deze stimulatie van voeropname, melkproductie en vetmobilisatie een klinische acidose veroorzaakt. 
Dit soort interacties van oorzaak en gevolg zijn weinig onderzocht met een gecontroleerde proefopzet. Er geen metingen bekend van de energetische consequenties van een acidose in melkvee. Er is veel bekend over het ontstaan van een (suklinische) pensacidose en de gevolgen daarvan op de vertering van met name celwanden. Ook is er veel bekend over het ontstaan van ketose als gevolg van een ophoping van ketonzuren in bloed, en hoe dit te voorkomen met glucogene precursors die de verwerkingscapaciteit van de lever stimuleren. Tevens goed onderzocht is de invloed van anionrijke, verzurende rantsoenen op het Ca metabolisme dat kritisch is in de periode rondom afkalven (i.v.m. voorkomen het Ca gebrek bij melkziekte). Er is relatief weinig informatie over het ontstaan en de gevolgen van een acidose in de dikke darm van melkvee. Ook is echter weinig bekend over de metabole consequenties voor de melkkoe van een metabole acidose, en hoe deze geïnitieerd kan worden wordt aanvullende problemen zoals een infectie of andersoortige immuunrespons, watergebrek, hittestress, ademhalingsproblemen, e.d. Het minst onderzocht lijkt echter de interacties tussen pensacidose, dikke darmacidose en metabole acidose. 


\section{$7 \quad$ Voorstellen voor verder onderzoek}

Op basis van de besproken achtergronden en de gevolgen van een pensacidose, dikke darmacidose en/of een metabole acidose, en het grotendeels ontbreken van literatuur met gecontroleerde experimenten waarin deze gelijktijdig onderzocht zijn, wordt de volgende voorstellen gedaan voor experimenteel onderzoek met melkvee in de transitieperiode waarin wordt gepoogd om tijdens de vroege lactatie onder gecontroleerde omstandigheden de oorzaken en gevolgen van acidose aan te tonen :

Metabole acidose

- Het kunstmatig opwekken van een ketose (gecontroleerd door intraveneus infuus met ketonzuren) en nagaan of een kationrijk vs. kationarm rantsoen invloed heeft op de mobilisatie van lichaamsvet, de mate van metabole verzuring en de energiehuishouding van de melkkoe

- Het kunstmatig opwekken van een ketose (gecontroleerd door intraveneus infuus met ketonzuren) in combinatie met het opwekken van een niet-infectueuze immuunresponse (d.m.v. het intraveneus inbrengen van lipopolysacchariden) om na te gaan hoe de bloedparameters wijzigen, en of dit samengaat met een vergroting van de negatieve energiebalans, een stimulatie van de mobilisatie van lichaamsvet en een vergroting van de negatieve eiwitbalans

\section{Pensacidose}

- $\quad$ Het opwekken van een pensacidose en nagaan welke gevolgen dit heeft voor de voedingswaarde van het rantsoen (vertering), welke gevolgen dit heeft voor de energiehuishouding en de mobilisatie van lichaamsvet, welke gevolgen dit heeft voor de permeabiliteit van pensepitheel (d.m.v. gecontroleerd infuus van lipopolysacchariden in de pens), welke gevolgen dit heeft voor een acidose in de dikke darm, welke immuunrespons dit teweeg brengt, en welke gevolgen dit heeft voor de mate waarin een metabole acidose optreedt.

\section{Dikke darmacidose}

- Het opwekken van een acidose in de dikke darm en nagaan welke gevolgen dit heeft voor de voedingswaarde van het rantsoen (vertering), welke gevolgen dit heeft voor de energiehuishouding en de mobilisatie van lichaamsvet, en welke gevolgen dit heeft voor de permeabiliteit van het dikke darmepitheel (d.m.v. gecontroleerd infuus van lipopolysacchariden in de dikke darm), welke immuunrespons dit teweeg brengt, in welke mate dit de eiwitbalans beïnvloedt, en welke gevolgen dit heeft voor de mate waarin een metabole acidose optreedt.

Aantonen van genoemde vicieuze cirkels

- $\quad$ Het onderzoeken of de vicieuze cirkel "mobilisatie vetweefsel - ketose - katabole status/mobilisatie " op te wekken valt

- Het onderzoeken of de vicieuze cirkel "negatieve energiebalans - immuunrespons - negatieve energiebalans" op te wekken valt

- $\quad$ Het onderzoeken of de vicieuze cirkel "lage voeropname - pensacidose met hogere krachtvoergift metabole acidose" op te wekken valt

- Het onderzoeken of de vicieuze cirkel "metabole acidose - hogere vetmobilisatie - hogere melkproductie - hogere voeropname - sterkere metabole acidose" op te wekken valt 


\section{Conclusies}

Er zijn relatief weinig onderzoeksresultaten beschikbaar rondom de causale relaties tussen het optreden van pensacidose, dikke darmacidose en metabole acidose. Verreweg het meeste onderzoek richt zich op uitsluitend een van de drie type acidoses (en dan nog vooral op pensacidose), maar niet op hun interactie en de samenhang met de immuunrespons, insuline-spiegels, insulineresistentie, mobilisatie van lichaamsvet en een melkkoe in een sterk katabole fysiologische status. Op basis van de beschikbare kennis ligt het echter in de in de lijn van de verwachting dat dergelijke interacties van groot belang kunnen zijn voor de melkkoe tijdens de lactatiestart en vroege lactatie. Qua beschreven mechanismen ligt het bovendien voor de hand dat er dusdanig interacties kunnen optreden dat de metabole problemen voor de melkkoe toenemen vanwege deze interacties. Er zijn geen metingen bekend voor de energetische en eiwitkosten die gemoeid gaan met het optreden van acidose, maar het is de verwachting dat deze aanzienlijk kunnen zijn en daarmee bijdragen aan de benodigde behoefte aan energie en eiwit. Daarmee zouden deze problemen ook grote invloed hebben op de grootte van de negatieve energie- en eiwitbalans tijdens de vroege lactatie, en daarmee op prestaties van de melkkoe, efficiënte benutting van nutriënten, en op formulering van het rantsoen. 


\section{Literatuur}

Apper-Bossard E., Faverdin P., Meschy F., Peyraud J.L. 2010. Effects of dietary cation-anion difference on ruminal metabolism and blood acid-base regulation in dairy cows receiving 2 contrasting levels of concentrate in diets. Journal of Dairy Science 93: 4196-4210.

Baldwin R.L. 1995. Modeling Ruminant Digestion and Metabolism. Chapman \& Hall Ltd, London, United Kingdom, p.578.

Bannink A., Valk H., van Vuuren A.M. 1999. Intake and excretion of sodium, potassium, and nitrogen and the effects on urine production by lactating dairy cows. J. Dairy Sci. 82: 1008-1018.

Bannink A., Dijkstra J. 2006. Voorspelling van de zuurgraad van pensvloeistof. Vertrouwelijk rapport 12, Animal Sciences Group, Lelystad.

Bannink A., Dijkstra J., Koopmans S.J., Mroz Z. 2006. Physiology, regulation and multifunctional activity of the gut wall, a rationale for multicompartmental modelling. Nutr. Res. Rev. 19: 227-253.

Bannink A., France J., Lopez S., Gerrits W.J.J., Kebreab E., Tamminga S., Dijkstra J. 2008. Modelling the implications of feeding strategy on rumen fermentation and functioning of the rumen wall. Anim. Feed Sci. Technol. 143: 3-26.

Bannink A., Gerrits W.J.J., France J., Dijkstra J. 2012. Variation in rumen fermentation and the rumen wall during the transition period in dairy cows. Anim. Feed Sci. Technol. 172: 80-94.

Bannink A., van Lingen H.J., Ellis J.L., France J., Dijkstra J. 2016. The contribution of mathematical modeling to understanding dynamic aspects of rumen metabolism. Front. Microbiol. 7: 1820.

Bradford B.J. Inflammation, immune function, and the transition cow.

Beauchemin K.A., Eriksen L., Nørgaard P., Rode L.M. 2008. Short Communication: salivary secretion during meals in lactating dairy cattle. J. Dairy Sci. 91: 2077-2081.

Bigner D.R., Goff J.P., Faust M.A., Burton J.L., Tyler H.D., Horst R.L. 1996. Acidosis effects on insuline response during glucose tolerance test in Jersey cows. J. Dairy Sci. 79: 2182-2188.

Dieho K. 2017. Aspects of rumen adaptation in dairy cattle. Morphological, functional, and gene expression changes of the rumen papillae and changes in the rumen microbiota during the transition period. PhD Thesis, Wageningen University \& Research, Wageningen.

Dijkstra J., Boer H., Van Bruchem J., Bruining M., Tamminga S. 1993. Absorption of volatile fatty acids from the rumen of lactating dairy cows as influenced by volatile fatty acid concentration, $\mathrm{pH}$ and rumen liquid volume. Br. J. Nutr. 69: 385-396.

Dijkstra J., Ellis J.L., Kebreab E., Strathe A.B., López S., France J., Bannink A. 2012. Ruminal pH regulation and nutritional consequences of low pH. Anim. Feed Sci. technol. 172: 22-33.

Dionissopoulos L., Laarman A.H., AlZahal O., Greenwood S.L., Steele M.A., Plaizier J.C., Matthews J.C., McBride B.W. 2013. Butyrate-mediated genomic changes involved in non-specific host defences, matrix remodelling and the immune response in the rumen epithelium of cows afflicted with subacute ruminal acidosis. Am. J. Anim. Vet. Sci. 8: 8-27.

Drackley, J.K., 1999. Biology of dairy cows during the transition period: the final frontier? J. Dairy Sci. 82: 2259-2273.

Ellis, J.L., C.K. Reynolds, L.A. Crompton, M.D. Hanigan, A. Bannink, J. France, J. Dijkstra. 2016. Prediction of portal and hepatic blood flow from intake level data in cattle. Journal of Dairy Science 99: 9238-9253.

Emmanuel D.G.V., Madsen K.L., Churchill T.A., Dunn S.M., Ametaj B.N. 2007. Acidosis and lipopolysaccharide from Escherichia coli B:055 cause hyperpermeability of rumen and colon tissues. J. Dairy Sci. 90: 5552-5557.

Emmanuel D.G.V., Dunn S.M., Ametaj B.N. 2008. Feeding high proportions of barley grain stimulates an inflammatory response in dairy cows. J. Dairy Sci. 91: 606-614.

Enemark J.M., Jorgensen R.J., Enemark P.St. 2002. Rumen acidosis with special emphasis on diagnostic aspects of subclinical rumen acidosis: a review. Veterinarija ir Zootechnika 20: 16-29.

Esposito G., Irons P.C., Webb E.C., Chapwanya A. 2017. Interactions between negative energy balance, metabolic diseases, uterine health and immune response in transition dairy cows. Unpublished, University of Pretoria, South Africa. 
Fredeen A.H., DePeters E.J., Baldwin R.L. 1988. Effects of acid-base disturbances caused by differences in dietary fixed ion balance on kinetics of calcium metabolism in ruminants with high calcium demand. J. Anim. Sci. 66: 174-184.

Gareau M.G., Silva M.A., Perdue M.H. 2008. Pathophysiological mechanisms of stress-induced intestinal damage. Curr. Mol. Med. 8: 274-281.

Giger-Riverdin S., Duvaux-Ponter C., Sauvant D., Martin O., Nunes do Prado I., Muller R. 2002. Intrinsic buffering capacity of feedstuffs. Anim. Feed Sci. Technol. 96: 83-102.

Gill M., Beever D.E., France J. 1989. Biochemical bases needed for the mathematical representation of whole animal metabolism. Nutr. Res. Rev. 2: 181-200.

Goff J.P. 2018. Invited review: Mineral absorption mechanisms, mineral interactions that affect acidbase and antioxidant status, and diet considerations to improve mineral status. J. Dairy Sci. 101: 2763-2813.

Gordon J.L. 2013. Risk factors for and treatment of ketosis in lactating dairy cattle. Thesis for Doctorate of Veterinary Science in Population Medicine. University of Guelph, Canada.

Goselink R.M.A., van Baal J., Widjaja H.C.A., Dekker R.A., Zom R.L.M., de Veth M.J., van Vuuren A.M. 2013. Effect of rumen-protected choline supplementation on liver and adipose gene expression during the transition period in dairy cattle. J. Dairy Sci. 96: 1102-1116.

Gregorini P., Beukes P.C., Waghorn G.C., Pacheco D., Hanigan M.D. 2015. Development of an improved representation of rumen digesta outflow in a mechanistic and dynamic model of a dairy cow, Molly. Ecol. Mod. 313: 293-306.

Grünberg W., Donkin S.S., Constable P.D. 2011. Periparturient effects of feeding a low dietary cationanion difference diet on acid-base, calcium, and phosphorus homeostasis and on intravenous glucose tolerance test in high-producing dairy cows. J. Dairy Sci. 94: 727-745.

Jing L., Zhang R., Liu Y., Zhu W., Mao S. 2014. Intravenous lipopolysaccharide challenge alters ruminal microbiota and disrupts ruminal metabolism in dairy cattle. Br. J. Nutr. 112: 170-182.

Li S., Khafipour E., Krause D.O., Kroeker A., Rodriguez-Lecompte J.C., Gozho G.N., Plaizier J.C. 2012. Effects of subacute ruminal acidosis challenges on fermentation and endotoxins in the rumen and hindgut of dairy cows. J. Dairy Sci. 95: 294-303.

Liu J., Xu T., Liu Y., Zhu W., Mao S. 2013. A high-grain diet causes massive disruption of ruminal epithelial tight junctions in goats. Am. J. Physiol., Regul. Integr. Comp. Physiol. 305: R232-241.

López S., Hovell F.D.D., Dijkstra J., France J. 2003. Effects of volatile fatty acids supply on their absorption and on water kinetics in the rumen of sheep sustained by intragastric infusions. J. Anim. Sci. 81: 2609-2616.

Maekawa M., Beauchemin K.A., Christensen D.A. 2002. Effect of concentrate level and feeding management in chewing activities, saliva production, and ruminal $\mathrm{pH}$ of lactating dairy cows. J. Dairy Sci. 85: 1165-1175.

Mills J.A.N., Crompton L.A., Ellis J.L., Dijkstra J., Bannink A., Hook S., Benchaar C., France J. 2014. A dynamic model of lactic acid metabolism in the rumen. J. Dairy Sci. 97: 2398-2414.

Oetzel G.R., Fettman M.J., Hamar D.W., Olson J.D. 1991. Screening of anionic salts for palatability, effects on acid-base status, and urinary calcium excretion in dairy cows. J. Dairy Sci. 74: 965-971.

Penner G.B., Beauchemin K.A. 2010. Variation among cows in their susceptibility to acidosis: challenge or opportunity ? Adv. Dairy Tech. 2: 173-187.

Plaizier J.C., Khafipour E., Li S., Gozho G.N., Krause D.O.. 2012. Subacute ruminal acidosis (SARA), endotoxins and health consequences. Animal Feed Sci. Technol. 172: 9-21.

Robinson P.H., Tamminga S., van Vuuren A.M. 1986. Influence of declining level of feed intake and varying the proportion of starch in the concentrate on rumen fermentation in dairy. Livest. Prod. Sci. 15: 173-189.

Robinson P.H., Tamminga S., van Vuuren A.M. 1987a. Influence of declining level of feed intake and varying the proportion of starch in the concentrate on milk production and whole tract digestibility in dairy cows. Livest. Prod. Sci. 17: 19-35.

Robinson P.H., Tamminga S., van Vuuren A.M. 1987b. Influence of declining level of feed intake and varying the proportion of starch in the concentrate on rumen ingesta quantity, composition and kinetics of ingesta turnover in dairy cows. Livest. Prod. Sci. 17: 37-62.

Roche J.R., Bell A.W., Overton T.R. Loor J.J. 2013. Nutritional management of the transition cow in the 21st century - a paradigm shift in thinking. Animal Production Science 53: 1000-1023. 
Sinclair K.D., Rutherford K.M.D., Wallace J.M., Brameld J.M., Stöger R., Alberio R., Sweetman D., Gardner D.S., Perry V.E.A., Adam C.L., Ashworth C.J., Robinson J.E., Dwyer C.M. 2016. Epigenetics and developmental programming of welfare and production traits in farm animals. Repr. Fert. Developm. 28: 1443-1478.

Spek J.W., Bannink A., Gort G., Hendriks W.H., Dijkstra J. 2012. Effect of sodium chloride intake on urine volume, urinary urea excretion, and milk urea concentration in lactating dairy cattle. J. Dairy Sci. 95: 7288-7298.

Suarez B.J., van Reenen C.G., Gerrits W.J.J., Stockhofe N., van Vuuren A.M., Dijkstra J. 2006. Effects of supplementing concentrates differing in carbohydrate composition in veal calf diets: II. Rumen development. J. Dairy Sci. 89: 4376-4386.

Summers M., McBride B.W., Milligan L.P. 1988. Components of basal energy expenditure. In: A. Dobson \& M.J. Dobson (Eds.), Aspects of Digestive Physiology in Ruminants. Comstock Publishing Associates, Ithaca, United States of America, pp. 257-285.

University \& Research, Wageningen.

Van Vuuren A.M., Van der Koelen C.J., Vroon-de Bruin J. 1993. Ryegrass versus corn starch or beet pulp fibre diet effects on digestion and intestinal amino acids in dairy cows. J. Dairy Sci. 76: 26922700.

Zarrin M., De Matteis L., Vernay M.C., Wellnitz O., van Dorland H.A., Bruckmaier R.M. 2013. Long-term elevation of $\beta$-hydroxybutyrate in dairy cows through infusion: effects on feed intake, milk production, and metabolism. Journal of Dairy Science 96: 2960-2972.

Zhang R., Zhu W., Mao S. 2016. High-concentrate feeding upregulates the expression of inflammationrelated genes in the ruminal epithelium of dairy cattle. Journal of Animal Science and Biotechnology $7: 42$.

Zom R.L.G., van Baal J., Goselink R.M.A., Bakker J.A., de Veth M.J. 2011. Effect of rumen-protected choline on performance, blood metabolites, and hepatic triacylglycerols of periparturient dairy cattle. J. Dairy Sci. 94: 4016-4027. 


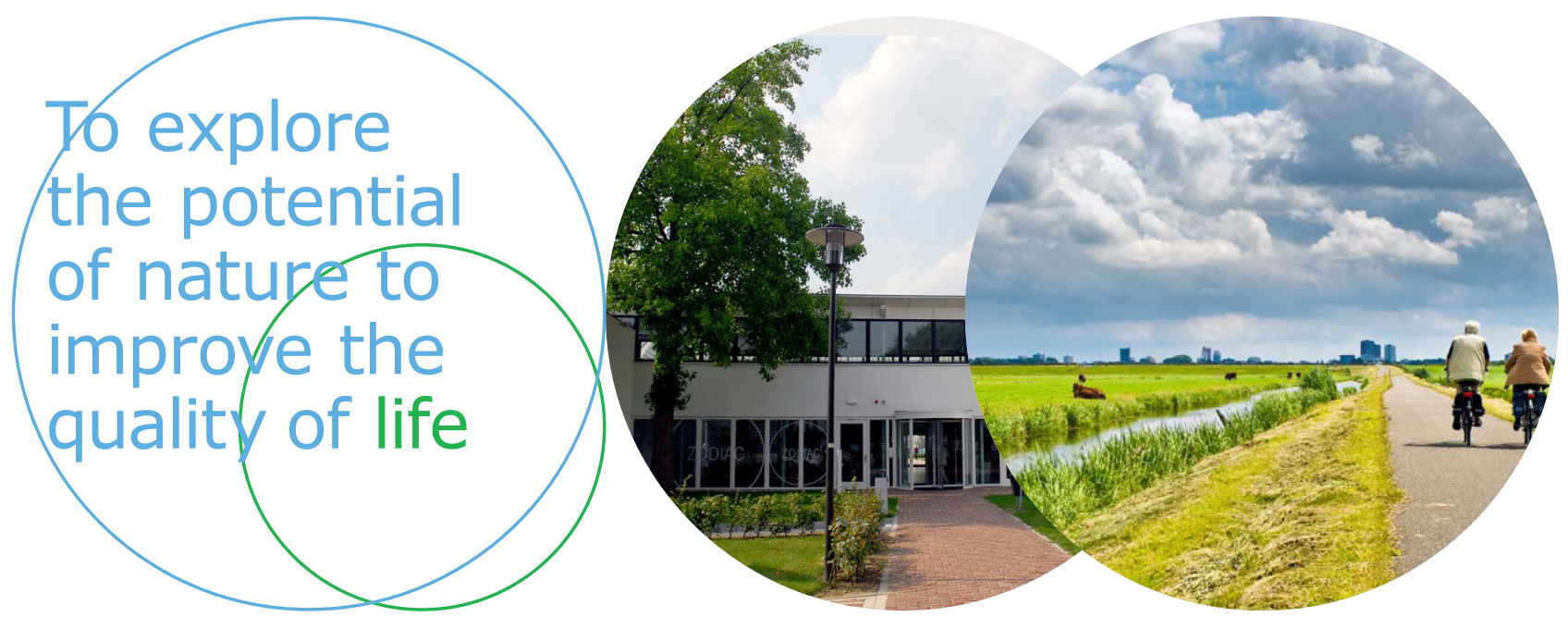

Wageningen Livestock Research Postbus 338

Wageningen Livestock Research ontwikkelt kennis voor een zorgvuldige en $6700 \mathrm{AH}$ Wageningen

T 0317483953

renderende veehouderij, vertaalt deze naar praktijkgerichte oplossingen en innovaties, en zorgt voor doorstroming van deze kennis. Onze wetenschappelijke E info.livestockresearch@wur.nl www.wur.nl/ livestock-research kennis op het gebied van veehouderijsystemen en van voeding, genetica, welzijn en milieu-impact van landbouwhuisdieren integreren we, samen met onze klanten, tot veehouderijconcepten voor de $21 \mathrm{e}$ eeuw.

De missie van Wageningen University \& Research is 'To explore the potential of nature to improve the quality of life'. Binnen Wageningen University \& Research bundelen 9 gespecialiseerde onderzoeksinstituten van Stichting Wageningen Research en Wageningen University hun krachten om bij te dragen aan de oplossing van belangrijke vragen in het domein van gezonde voeding en leefomgeving. Met ongeveer 30 vestigingen, 6.500 medewerkers en 10.000 studenten behoort Wageningen University \& Research wereldwijd tot de aansprekende kennisinstellingen binnen haar domein. De integrale benadering van de vraagstukken en de samenwerking tussen verschillende disciplines vormen het hart van de unieke Wageningen aanpak. 